\title{
Phenotyping Brown Rot Susceptibility in Stone Fruit: A Literature Review with Emphasis on Peach
}

\author{
Majid Hassan Mustafa ${ }^{1}$, Daniele Bassi ${ }^{1}$, Marie-Noëlle Corre ${ }^{2}$, Leandro Oliveira Lino ${ }^{2}$, Véronique Signoret ${ }^{2}$, \\ Bénédicte Quilot-Turion ${ }^{2, *}$ (1) and Marco Cirilli ${ }^{1, *}$ \\ 1 Department of Agricultural and Environmental Sciences (DISAA), University of Milan, 20133 Milan, Italy; \\ majid.mustafa@unimi.it (M.H.M.); daniele.bassi@unimi.it (D.B.) \\ 2 INRAE, GAFL, F-84143 Montfavet, France; marie-noelle.corre@inrae.fr (M.-N.C.); \\ oliveiralino.leandro@gmail.com (L.O.L.); veronique.signoret@inrae.fr (V.S.) \\ * Correspondence: benedicte.quilot-turion@inrae.fr (B.Q.-T.); marco.cirilli@unimi.it (M.C.)
}

\section{check for}

updates

Citation: Mustafa, M.H.; Bassi, D.; Corre, M.-N.; Lino, L.O.; Signoret, V.; Quilot-Turion, B.; Cirilli, M.

Phenotyping Brown Rot

Susceptibility in Stone Fruit: A

Literature Review with Emphasis on Peach. Horticulturae 2021, 7, 115.

https://doi.org/10.3390/

horticulturae7050115

Academic Editors: Harald Scherm and Douglas D. Archbold

Received: 14 March 2021

Accepted: 12 May 2021

Published: 17 May 2021

Publisher's Note: MDPI stays neutral with regard to jurisdictional claims in published maps and institutional affiliations.

Copyright: (c) 2021 by the authors. Licensee MDPI, Basel, Switzerland. This article is an open access article distributed under the terms and conditions of the Creative Commons Attribution (CC BY) license (https:/ / creativecommons.org/licenses/by/ $4.0 /)$.

\begin{abstract}
Plant disease phenotyping methodologies can vary considerably among testers and often suffer from shortcomings in their procedures and applications. This has been an important challenge in resistance breeding to brown rot, one of the most severe pre-and postharvest stone fruit diseases caused by Monilinia spp. Literature about methodologies for evaluating stone fruit susceptibility to brown rot is abundant but displays significant variations across the described approaches, limiting the ability to compare results from different studies. This is despite the fact that authors largely agree on the main factors influencing brown rot development, such as Monilinia inocula, environmental conditions, cultivars, fruit stage, and management practices. The present review first discusses ways to control or at least account for major factors affecting brown rot phenotyping studies. The second section describes in detail the different steps of fruit infection assays, comparing different protocols available in the literature with the objective of highlighting best practices and further improvement of phenotyping for brown rot susceptibility. Finally, experimental results from multi-year evaluation trials are also reported, highlighting year-to-year variability and exploring correlations of evaluation outcomes among years and assay types, suggesting that choice of phenotyping methodology must be carefully considered in breeding programs.
\end{abstract}

Keywords: brown rot; inoculum application; Monilinia; phenotyping; phenotypic instability; stone fruit

\section{Introduction}

Brown rot (BR) caused by Monilinia spp. is one of the most destructive diseases in commercial stone fruit orchards worldwide. M. fructicola (G. Winter) honey, M. laxa (Aderh and Ruhland) honey, and M. fructigena (Aderh. and Ruhland) honey are the main species causing fruit infections [1]. These fungi incite losses by infecting blossoms, flowers, and fruit during the preharvest, harvest, and postharvest periods [2]. Postharvest losses can be particularly severe, especially when conditions are favorable for disease development; in some cases, $80-85 \%$ of a crop may be lost [2,3]. When weather conditions are unfavorable, infections may remain latent until conditions become favorable for disease expression, at which point fruit rot ensues [4].

Currently, cultural practices and frequent fungicide applications are the main management measures to control BR in the field, although emerging Monilinia isolates resistant to fungicides have been reported $[5,6]$. Therefore, developing and assessing cultivars with resistance traits against $\mathrm{BR}$ has been the primary goal of several breeding programs.

Classic breeding approaches are time-consuming due to lengthy procedures for evaluating resistance on field-grown segregating progenies. Therefore, an important objective is to develop new tools to screen seedlings with enhanced BR resistance. Marker-assisted selection (MAS) is a valuable strategy for this purpose, as it allows the early selection of seedlings bearing favorable alleles at marker loci associated with genomic regions that 
control the trait of interest. In stone fruit, the mapping of quantitative trait loci (QTL) on populations derived from bi-parental crosses is presently applied [7-9]. However, genetic analyses require accurate phenotypic data for the estimation of genotype-associated variation of the trait.

$\mathrm{BR}$ resistance is a complex trait requiring robust, easy to apply, inexpensive and effective phenotyping methods. Many stone fruit breeders have developed protocols aiming at BR susceptibility evaluation on fruit [10-14]. Some are applied in the field, others in controlled conditions (laboratory); some are easy to use, whereas others involve laborious procedures. However, a complete understanding of the process that contributes to effective disease phenotyping is crucial for results to be reliable and repeatable. Protocols are highly dependent on adequately performing different steps. In addition, other factors influence the development of BR and also directly affect the phenotyping process. No comprehensive review is available on phenotyping methodologies for brown rot susceptibility in stone fruit to this extent.

Therefore, this review focuses on essential phenotyping protocols and procedures applied in breeding programs and cultivar evaluations for BR susceptibility in stone fruits. The objectives were to (i) summarize essential factors for BR development and phenotyping, (ii) review the protocols applied in the field and laboratory for artificial BR infection, and (iii) discuss consequences and instability in phenotyping, also in light of recent unpublished experimental results from our group.

\section{Factors Influencing Brown Rot Development}

The critical life stages of Monilinia spp., such as primary inoculum availability, host infection and colonization, and secondary inoculum, are the essential prerequisites for the development of BR infection. Multiple factors influence the completion of these life stages, and their knowledge is critical to developing optimized phenotyping protocols.

Principally, the brown rot life cycle includes different stages [1]: blossom blight and twig canker at early spring, brown rot at late spring and summer, latent infections, and overwintered inoculum in the form of mummified fruit on trees or orchard ground.

Monilinia spp. overwinters and produces primary inoculum from two sources: mycelia in the fruit mummies, fruit peduncles, cankers on twigs and branches, leaf scars, and buds that sporulate under favorable condition; and stromata that produce ascospores in the spring [1,15-19]. However, mummies hanging on trees appeared to be a more viable and effective source of primary inoculum than ground mummies [20].

Secondary inoculum can emerge from any infected tissue in which the moisture content is sufficient for sporulation [1]; however, non-abscised (aborted) fruit on trees and thinned fruit on the orchard floor appeared to be critical sources in certain production regions $[21,22]$.

Some authors remark the importance of quiescent infections on developing or ripening fruit that may become active when fruit mature before or after harvest [23]. Latent infection can be particularly relevant postharvest [24]. Molecular techniques have been developed for detecting latent infections in stone fruit $[25,26]$. Latent infection is critical for postharvest BR epidemiology, although it is less discussed at the breeding level.

\subsection{Environment}

Environment plays an essential role in disease development [27]. Variables such as temperature, photoperiod (light), humidity, and leaf wetness modulate canopy environment and influence fruit growth and quality [28], as well as BR development. For Monilinia spp., the most critical environmental factors seem to be temperature and humidity. Under favorable conditions, the process of Monilinia infection starts with the conidium germination on the fruit surface, followed by elongation of the germ tube and formation of appressoria to penetrate the epidermis [29] or to enter through natural openings and wounds [30]. Under adverse conditions, primary infections can remain latent in blossoms and immature fruits $[23,31]$. 
Temperature and humidity are primary factors to be considered in the Monilinia spp. life cycle. The optimum temperature for mycelial development and sporulation was about $25^{\circ} \mathrm{C}$ for all BR fungi [1]. However, for most Monilinia spp., the optimum temperature for mycelial growth ranges from 15 to $20^{\circ} \mathrm{C}$, and only M. laxa requires $25^{\circ} \mathrm{C}$ [32]. Regarding $M$. fructicola germination, the best temperature range has been reported at $15-25^{\circ} \mathrm{C}$ or $21-27^{\circ} \mathrm{C}$, depending on the study $[33,34]$. More recently, analyzing the influence of temperature on fruit infection, Biggs and Northover [35] suggested that optimum temperature for cherry and peach BR infection by $M$. fructicola ranged from 20 to $22.5^{\circ} \mathrm{C}$ and 22.5 to $25^{\circ} \mathrm{C}$, respectively.

Bernat et al. [36] modeled and compared the effects of temperature on brown rot, mycelia development, and sporulation on peaches and nectarines for M. fructicola and M. laxa. They showed a better adaptation of M. fructicola and M. laxa to high and low temperatures, respectively. Notably, the capacity of M. fructicola and M. laxa to infect fruit seems to be maintained across an extensive temperature range, between 0 and $30^{\circ} \mathrm{C}$ [36]. In addition, the two species significantly differ in infection and colonization speed, whereby M. fructicola is more aggressive, causing larger fruit lesions and having shorter periods of both incubation and latency [37]. However, the risk of Monilinia infection is significantly reduced at low temperatures [38].

Several reasons can explain discrepancies among studies: relative humidity and/or temperature-by-humidity interactions; the different optimal temperatures required for fungal functions, such as germination, mycelial growth, and sporulation; variations in temperature requirements putatively existing between geographic isolates of $M$. fructicola: e.g., isolates from blossoms, which develop during cool springs, grow at lower temperatures than those developing on fruit [39]. However, temperatures deviating from the optimum mainly cause a delay of germination but have a limited effect on the final infection success [40].

Wetness or relative humidity (RH) influence the initiation and development of BR in many inter-related ways. In sweet cherry, BR incidence by $M$. fructicola doubled when wetness duration increased from 9 to $12 \mathrm{~h}$ and doubled again with further increase in wetness duration [35]. Similar results were also reported on peach, where a linear increase in disease incidence was observed over the same conditions. Likewise, blossom infections by M. laxa were significantly influenced by both temperature and duration of post-inoculation wetness [41]. The degree and course of wetness also influenced the success of penetration of nectarine surface and disease incidence [42]. In the same way, the penetration of peach blossoms by $M$. fructicola was greatly influenced by relative humidity [33]. In a saturated atmosphere, access occurred through any of the floral parts, except sepals, but at a relative humidity of $80 \%$ or lower, infection was only observed through stigmas [4]. A combination of those two factors determines the delay before infection and the likelihood of success. Under dry conditions at $15^{\circ} \mathrm{C}$, up to $40 \%$ of cherry blossoms were infected, while infections at different temperatures $\left(5,10\right.$, and $\left.20^{\circ} \mathrm{C}\right)$ were less frequent. In contrast, under $24 \mathrm{~h}$ post-inoculation wetness, up to $70-90 \%$ of blossoms were infected at each temperature tested [42].

Furthermore, wind is another crucial factor, as it could modify relative humidity and conidium dispersion through air turbulence [43], playing an essential role in disease spread.

Finally, rain is another significant factor in BR development, assisting in dispersing and spreading inocula and providing ideal relative humidity. Further information on the epidemiology of Monilinia spp. has been reviewed by Holb [44] and Rungjindamai et al. [45].

\subsection{Cultivars}

Despite being most relevant for breeding, qualitative sources of BR resistance have not been found in peach and other stone fruit. Some studies have identified accessions with partial quantitative resistance (often erroneously defined as highly tolerant), in which 
infection remains latent and/or a limited number of fruits per tree develop symptoms; however, available commercial cultivars are all relatively highly susceptible to BR. Such high susceptibility acts as a further contributor to BR development since infected fruit serve as a continuous inoculum source along the season. In peach, the Brazilian cultivar Bolinha is known to display the highest levels of BR partial resistance in terms of reduced rate of lesion development, sporulation per unit area, and, particularly, disease incidence [46,47]. This cultivar has been used as a BR resistance donor in conventional breeding for developing canning and low-chill peaches despite its poor fruit size and quality, high susceptibility to enzymatic browning, and high incidence of preharvest fruit drop. Besides the increased compactness of epidermal and sub-epidermal cells, the high fuzz and thick cuticle, Bolinha fruit contain a high amount of phenolic compounds compared to other BR-susceptible cultivars [48,49]. The case of 'Bolinha' demonstrates the challenge of breeding for BR resistance, as traits associated with fruit resistance may conflict with commercial requirements; however, among the primary objectives of some breeding programs, resistance against BR takes precedence.

In the peach breeding program at the University of Milan, Italy (started at the University of Bologna), an F1 population from a cross between 'Contender' $\times$ 'Elegant Lady' [50] resulted in a higher BR partial resistance level compared to the donor 'Contender' [8].

At UC Davis and USDA joint breading program, improved levels of BR partial resistance in some peach cultivars and advanced selections were reported. A progeny was generated by crossing the moderately resistant cultivar Dr. Davis with an introgression line ('F8,1-42') resistant to BR, originated from an almond $\times$ peach interspecific cross [7].

Furthermore, at the Clemson University peach breeding program, some degree of resistance has been reported in materials other than 'Bolinha' and interspecific hybrids (almond $\times$ peach). An advanced selection from the North Carolina State University peach breeding program 'NC97-45' ('Contender'; descendant) [51] was reported as more resistant to BR than parents [52], which supports the findings of Pacheco et al. [8] on 'Contender' as a source of partial resistance to BR.

In another program, the progeny from 'Texas' (almond) and 'Earlygold' (peach) backcross $(\mathrm{BC} 1)$ showed a wide range of severity and incidence of BR infection in wounded and non-wounded fruit [9]. Moreover, Nicotra et al. [53] have reported 11 advanced apricot selections and cultivars with BR-resistant traits. However, studies in many cherry cultivars failed to find promising accession with fruit resistance to BR [54-56]. In contrast to the low level of skin tolerance often found in peach, plum cultivars showed low [12] or no BR infection [57] in inoculated intact fruits. Thus, the outcome of inoculation of intact fruit surface (skin) seems unsuitable for artificially classifying plum fruit as BR tolerant since they are still sensitive in a natural condition or when fruit are wounded.

\subsection{Fruit Stage}

Fruit susceptibility to BR varies along with the phenological growth and development stage. Several studies have investigated these variations by evaluating infection probability at different fruit stages [58].

In peach, fruit development is divided into four stages (S1 to S4), all highly susceptible to Monilinia spp. except for S2 (pit hardening) [59]. The early fruit stage-related susceptibility to BR on stone fruit has been previously reported $[58,60]$.

The first stage (S1) starts after ovule fertilization or petal fall and ends at the beginning of stone lignification. The fruit is photosynthetically active at this stage, displaying intense transpiration activity and showing the highest nutrient content [61], resulting in increased susceptibility to BR, probably due to the stomata activity, providing an entry point to the pathogen [62].

The second stage (S2, pit hardening) is the most resistant to Monilinia spp. infection [58,63,64]; this stage is characterized by the accumulation of secondary metabolites, such as catechin, epicatechin, and phenolic compounds, associated with the lignification of the endocarp. In artificially wounded fruit, the temporary absence of susceptibility in S2 seems to be mainly associated with 
the biosynthesis of specific biochemical compounds rather than a higher mechanical resistance [58]. Contrary to other studies, even the pit hardening stage has been observed to be susceptible to BR infections, which remain latent until the ripening stages $[59,65]$.

During the third stage (S3), characterized by a high rate of cell expansion and ending at fruit physiological maturity, fruit become increasingly susceptible to pathogens, including BR. At fruit maturity (S4), BR susceptibility reaches its peak starting approximately two weeks before full ripening $[35,63]$. Similar patterns were previously reported for apricot and peach $[58,64]$. The progressive decrease in resistance-compounds concentration due to fruit growth and/or structural changes affecting surface integrity would seem the most plausible hypotheses for the increased susceptibility observed at these stages [48].

Also, in cherry, the susceptibility to M. fructicola fluctuates with the stage of fruit development [66]: young developing cherries become increasingly susceptible to infection, then they turn to be less susceptible at pit hardening and finally again become gradually more susceptible until harvest [56]. Moreover, the susceptibility to M. laxa under field conditions significantly increases with fruit maturity [56].

\subsection{Cultural Practices and Orchard Management}

Commonly applied practices in a stone fruit orchard, including crop load management, irrigation, fertilization, pruning, and canopy architecture, have a major impact on Monilinia spp. development [67]. Besides fungicide application, pruning blighted twigs and removal of mummified fruit are considered the most effective control measures against BR. Cultural practices can impact the inoculum source directly via microclimate modulation such as irrigation, pruning, fertilization, and indirectly via fruit thinning [68].

Mercier et al. [69] studied the combined effects of irrigation regime and pruning system. The lowest BR incidence occurred under a combination of water deprivation (about 30\% of the fully irrigated treatment) and 'long' pruning (i.e., dormant plus summer interventions for the removal of epicormic shoots and young, vigorous sprouts, without trimming) in comparison with full irrigation and 'short' pruning (i.e., dormant plus summer interventions of shoot trimming). Similarly, training system and pruning (shapes with a dominant central leader) seemed to reduce brown rot incidence compared to conventional system, e.g., 'vase' systems [70]. This effect could be due to improved light penetration and reduced relative humidity in the less dense canopies that negatively affected fungal germination and sporulation.

Gilbert et al. [71] have primarily studied the complex interplay between cultural practices, fruit growth, and BR infection risks. They showed that irrigation and fruit thinning affect fruit growth and the appearance of microcracks on the fruit surface. Frequent and high levels of irrigation on 'Zéphir' nectarine strongly increased the density of cuticular cracks compared to water-restricted trees receiving two- to three- times less water per day. Furthermore, low crop loads dramatically increased both fruit size and the incidence of cuticular microcracks, leading to increasing BR susceptibility.

Nevertheless, management of crop load concerning fruit BR susceptibility seems difficult to be optimized. Bellingeri et al. [72] reported opposite effects on trees subjected to different thinning treatments, with the highest BR infection observed in moderately thinned compared to intense or unthinned trees. This could be explained by a complex interaction between the probability of infection by contact (which tends to decrease along with fruit density) and cuticle cracking (which tends to increase in faster-growing fruit) (see Section 2.5).

Fertilization also seems to play a role in BR susceptibility. For example, peach trees subjected to a high level of compost exhibited a significant increase in M. fructicola incidence. Other studies investigated fertilization with calcium [73], zinc [74], and boron [75], reporting an enhancement of fruit quality and lowering of BR susceptibility. The effect of fertilization could result in a modification of tree growth, affecting canopy microclimate or increased fruit nitrogen content [76]. However, no clear correlation between seasonal changes of peach nutrient content and susceptibility to M. laxa was found [61]. 


\subsection{Fruit Characteristics}

Monilinia spp. can mainly enter the fruit via two ways, either by actively penetrating the fruit surface or through natural openings such as stomata or microcracks (Figure 1) [30,48,77-79]. However, Monilinia is also able to penetrate fruit skin directly without the need for wounds or natural openings, employing degrading enzymes and colonizing plant tissue similarly to other necrotrophic fungi [79-83].

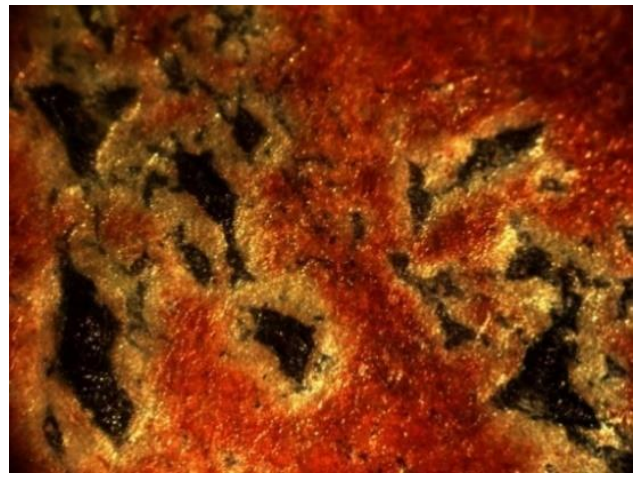

(a)

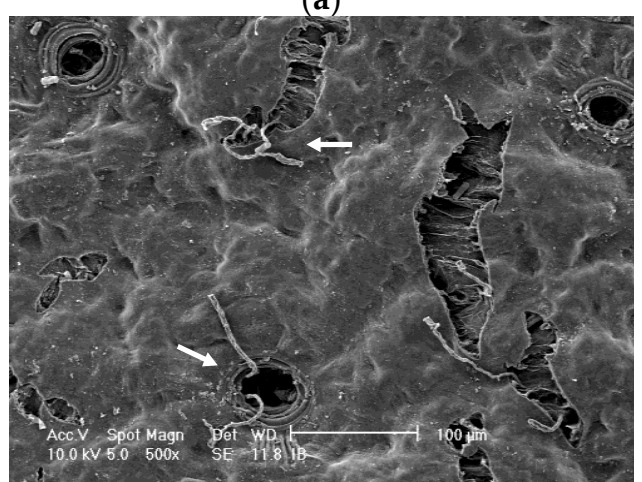

(c)

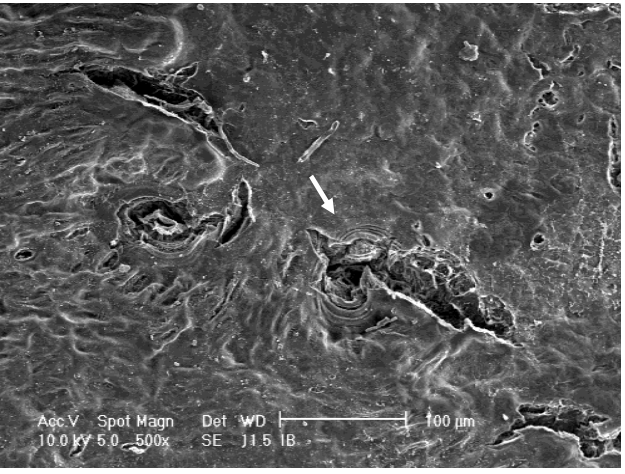

(b)

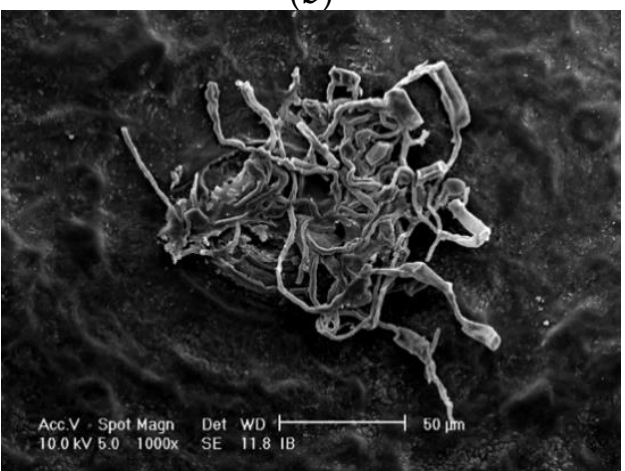

(d)

Figure 1. (a) Surface of the nectarine fruit 'Zéphir' at maturity with a dense network of microcracks under a stereomicroscope. Cracks were stained dark blue by applying toluidine blue at $0.1 \%$. (b) Scanning electron microscopy image showing microcracks originating from a lenticel, presumably derived from a stoma (arrow) on the fruit peel of nectarine 'C222' selection. (c) Scanning Electron Microscopy image showing spores of M. laxa germinating (arrows) in the microcracks of mature nectarine fruit of cultivar Magic. (d) Scanning Electron Microscopy showing the development of $M$. laxa mycelia in a lenticel on the fruit peel of 'C222' selection.

Besides chemical factors such as nutrients and volatiles, fruit surface characteristics such as hydrophobicity and topography are common appressorial inducers for many fungi. In nectarine fruit, the formation of $M$. fructicola appressoria at the S2 stage and their absence at the $\mathrm{S} 3$ stage seem to be associated with the respective high and low peel hydrophobicity [29].

Although Monilinia is a necrotrophic fungus that can infect fruit via direct penetration, fruit cracks are well-known to be the preferential entry ports [84,85]. Different fruit characteristics can be accounted for reducing susceptibility to BR, which most of these defense barriers, either mechanical or biochemical, are related to the epidermis [12,46,48]. Considering the active penetration of the fungi, the composition of the different epidermis layers and the mechanical traits linked to surface integrity seem to be the main characteristics to be explored in addition to active biochemical defense mechanisms.

The plant cuticle is the first protective barrier to biotic stresses, as it contains antimicrobial compounds involved in plant-pathogen interactions. However, until recently, few studies have explored the cuticle of Prunus fruit. Oliveira Lino et al. [60] studied the cuticu- 
lar wax composition of three nectarine cultivars and its change during fruit development in correspondence to skin conductance and susceptibility to M. laxa. Cuticular waxes greatly varied both quantitatively and qualitatively throughout fruit growth. The high skin conductance in the early stages was attributed to the high density of functional stomata in young fruit and the absence of the wax layer not yet formed. Moreover, this absence might have also facilitated direct infection by $M$. laxa at the early stages. The variation of cuticular wax deposition may also explain their contribution to BR resistance at pit hardening and, conversely, the susceptibility of mature fruit (showing a higher level of alkane waxes, which could favor the fungus growth).

Skin cracks are an essential factor affecting the integrity of fruit surface integrity. The link between cracking and BR incidence suggests that fruit resistance factors provided by the epidermis are, of course, no longer influential when the cuticle loses its integrity [71]. Cuticular cracks are assumed to occur when the elastic limit of the cuticle is exceeded as a consequence of high internal pressure, especially during rapid fruit expansion [86,87]. Certain cultural practices mainly promote a fast-growing phase (see Section 2.4). Microscopic observations of fruit surface in three nectarines ('Zéphir', 'Magic', and 'C222') confirmed the formation of a dense network of microcracks in mature fruits and preferential spore germination inside the cracks (Figure 1). These observations suggest that BR resistance factors targeted in breeding programs should explore a combination of these two traits: low susceptibility to cracking and enhanced content of antifungal compounds.

\section{Protocols for BR Susceptibility Evaluation}

Some stone fruit breeders and scientists have developed protocols for BR susceptibility evaluation to be applied either in the field or controlled environments (laboratory); some are easy to use, whereas others involve laborious procedures. The goal commonly sought is a robust, fast, and low-cost protocol enabling the screening of a large number of progenies. This section reviews BR resistance phenotyping protocols used to evaluate artificial infection in stone fruit, focusing on cultivar evaluation and breeding programs.

Among the several prerequisites, assessed fruit should not receive fungicide treatments after flowering $[13,88]$ since fungicide residues could bias phenotyping results. Selected fruit should also be unblemished, uniform in size and maturity [47] since variations in the degree of ripeness and/or the presence of wounds or cracks could mislead conclusions about fruit susceptibility. Criteria and methods for establishing the degree of fruit maturity often vary across studies, ranging from visual assessment to the measurement of firmness, color, and/or soluble solids content (SSC) $[10,11]$. The use of the index of absorbance difference $\left(\mathrm{I}_{A D}\right)$ measured by a portable DA-Meter (TR Turoni, Forli, Italy) seems a reasonable and objective approach to standardize peach maturity evaluation $[11,14,89,90]$. In addition, a stereomicroscope was used to examine fruit surfaces with the aim of discarding injured fruit before inoculation [46]. However, this procedure is difficult to implement as a routine check.

\subsection{Fruit Preparations before Inoculation}

In laboratory assessments, fruit are carefully handpicked and usually subjected to preparations before inoculation [91]. Primarily, damaged and field-infected fruit are excluded [91] without considering possible latent infections coming from the field that have not yet been activated. Dissipating field heat or precooling of fruit is the first care to slow down biological activities. To this end, different fruit temperatures and treatment durations, for example, storage at $0,0.5$, and $4{ }^{\circ} \mathrm{C}$ for few days up to few weeks, have been tested $[7,11,57]$ until the day of assessment. However, prolonged storage is not recommended since low temperatures may interfere with critical physiological properties and modify fruit susceptibility. Storing fruit for short periods gives more flexibility to organize inoculation. For example, Gradziel et al. [46] kept fruit at $22{ }^{\circ} \mathrm{C}$ for $12 \mathrm{~h}$ to homogenize the batches harvested on different days and simulated the practice of fruit storage in the postharvest and commercialization period. 
Postharvest disinfection of fresh fruit is considered an essential step before handling [92]. Similarly, this practice has been employed in screening stone fruit for BR susceptibility before inoculation with Monilinia spp. to eliminate field contaminations or competing organisms that may interfere during artificial infection. Fruits were surfacesterilized by bleach at $10 \%$ or $8 \%$, with different concentrations of sodium hypochlorite ( $\mathrm{NaOCl})[7,36,53,54,90]$, calcium hypochlorite [93], or less concentrated chlorine solutions ranging from $0.5 \%$ to $2 \%[4,10,37,53,56,64,94]$. In addition, ethyl alcohol has been used as a surface sterilizer, mainly at $70 \%$ concentration, before or after disinfecting with chlorine compounds $[4,37,54]$. However, no consensus method for disinfecting fruit before inoculation emerged from these protocols, as different concentrations and combinations of hypochlorite, ethyl alcohol and timing have been used. However, in all methods, the process ends up carefully rinsing fruit in water to remove the disinfectants, followed by air drying. Overall, the treatments above might be considered as disruptive of the fruit surface and, putatively, a modification of its susceptibility to infection. This was the reason behind the use of only water for fruit cleaning in some studies [50,55].

Baró-Montel et al. [11] have thoroughly investigated the effect of different types and concentrations of disinfectants on wounded and non-wounded fruit before inoculation. They reported a lower disease severity in disinfected wounded fruit. However, in nonwounded fruit, a significant increase in disease severity was reported when the most aggressive $(10 \% \mathrm{NaClO})$ disinfectant treatment was applied. Finally, they also observed a rise in BR incidence after dipping the fruit in tap water without a disinfectant, suggesting that water could promote pathogen growth and facilitate the infection process.

The use of a water bath (recommended as a technique to reduce postharvest infections) deserves further attention. Spadoni et al. [95] have shown a stimulating effect on the germ tube of $M$. fructicola conidia on the fruit surface immediately after heat treatment at $60^{\circ} \mathrm{C}$ for $60 \mathrm{sec}$. Volatile organic compounds emitted from heat-treated peaches have been putatively implicated in the stimulation of conidium germination and the increased BR incidence when inoculation occurred immediately after bathing.

We further investigated the effect of water bath on BR infection on three nectarine cultivars. Twenty fruit per accession at commercial maturity were chosen and subjected to soaking in $55^{\circ} \mathrm{C}$ hot water for $45 \mathrm{~s}$. Then, fruit were air-dried at room temperature, followed by inoculating with droplet at concentration $10^{5}$ conidia $\mathrm{mL}^{-1}$ of M. laxa. In this experiment, a significant increase in BR infection probability was observed on water bathed fruit compared to unbathed ones (Figure 2). The effect of water bath on surface compounds for the cultivar Zéphir was also investigated. However, we detected no significant differences between the two treatments on the contents of triterpenoids or terpenoid derivatives in the fruit peel (data not shown). Even though these surface compounds were not affected, the water bath might influence other compounds such as proteins and water-soluble metabolites involved in the fruit-fungus interaction trade-off pathway. A similar increase in BR incidence has been reported for peach and nectarine [38] and nectarine 'Red Jim' fruit [24] when subjected to water dumping followed by incubating at $20^{\circ} \mathrm{C} 65-100 \% \mathrm{RH}$.

Even though fruit disinfection is an important operation in postharvest trials to avoid secondary infections, our results recommend utmost precautions before subjecting fruit to the water bath since this procedure seemed to increase the susceptibility of nectarine fruit to BR and may activate latent infections in postharvest handling. 


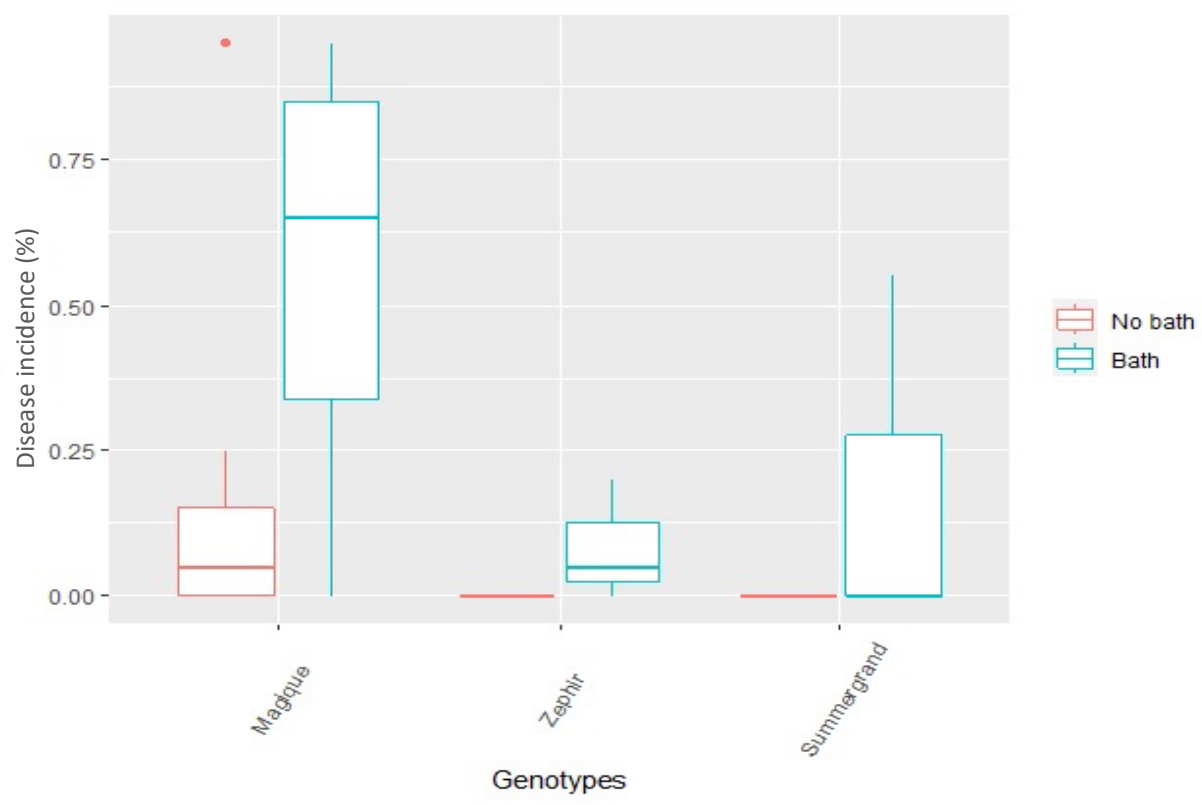

Figure 2. The effect of water bath on the brown rot disease incidence of three nectarine cultivars Magique, Zéphir, and Summergrand. Fruit were immersed in hot water $\left(55^{\circ} \mathrm{C}\right)$ for $45 \mathrm{~s}$. The air-dried fruit at room temperature were inoculated with a $10 \mu \mathrm{L}$ drop of $M$. laxa suspension at concentration $10^{5}$ conidia $\mathrm{mL}^{-1}(p$-value $<0.005)$.

\subsection{Strain Conservation and Inoculum Production}

Monilinia spp. culture could be maintained for long-term storage on different media such as potato dextrose agar (PDA) at $5{ }^{\circ} \mathrm{C}$ [96] or $4{ }^{\circ} \mathrm{C}$ [10], and $2 \%$ Malt extract agar at $2{ }^{\circ} \mathrm{C}$ in darkness [97]. There are other methods for storing fungi; for example, in our lab, we maintained Monilinia spp. spores in an aliquot of $20 \%$ glycerol with potassium dihydrogen phosphate buffer at -20 or $-80{ }^{\circ} \mathrm{C}$.

Before running any experiments, suitable quality inoculum should be prepared. Therefore, Monilinia spp. cultures are activated on nutrient media at optimum temperatures $\left(25^{\circ} \mathrm{C}\right)$. Inoculum preparation from a single-spore isolate allows using the same isolate throughout the experiment. However, some authors used the isolated Monilinia spp. directly from seasonal infected stone fruit: in this case, series of subcultures are needed to purify the inoculum from contaminants.

Moreover, the assessment of pathogenicity and virulence among Monilinia species revealed a significant variability even among isolates of each species $[65,94]$. Thus, it is recommended to check the stability of pathogenicity before running experiments. According to Koch's postulates, such a practice can be performed by infecting intact fruit (e.g., peach) [10]. In our lab, working on $M$. laxa and $M$. fructicola, we observed reduced growth competence of Monilinia spp. on V8 juice agar (V8A) after several subcultures. Therefore, we periodically regenerated new cultures from aliquots stored at $-20{ }^{\circ} \mathrm{C}$ or isolating from actively infected fresh fruit (Figure 3). This process was repeated every three months to maintain maximum growth speed.

Screening large progenies for BR susceptibility requires a tremendous amount of inoculum to be prepared weekly to achieve an identical concentration of viable conidia throughout the experiment. The media composition may impact the rapidity of growth and sporulation, the number of spores produced, and viability.

PDA and V8A are the most common media used for inoculum production for Monilinia; other less frequent media include peach or tomato juice agar and glucose-asparagine-yeast extracts (Table 1). Producing the inoculum directly on fruit is a valid and viable option (Figure 3), with the precaution of previous disinfection with alcohol. The use of canned fruit is also reported [13]. Phillips [98] reported that spores produced on PDA were less 
aggressive and smaller in size than those cultivated on peach and nectarine fruit. Hence, a culture media as V8A may be preferred for high quality and amount of sporulation.

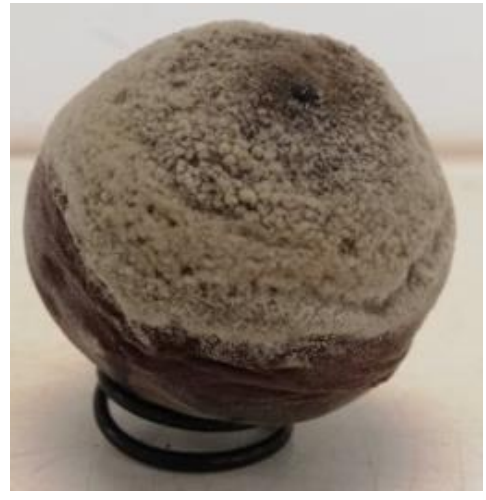

(a)

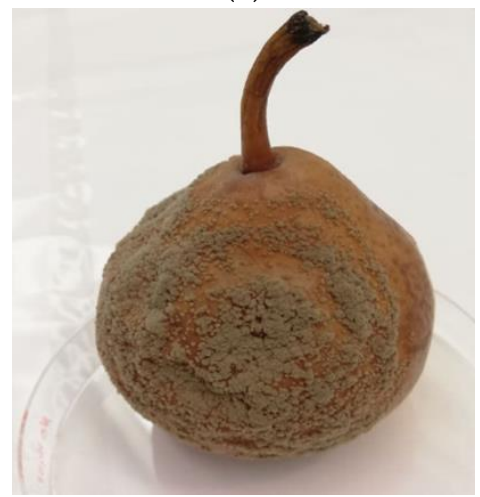

(c)

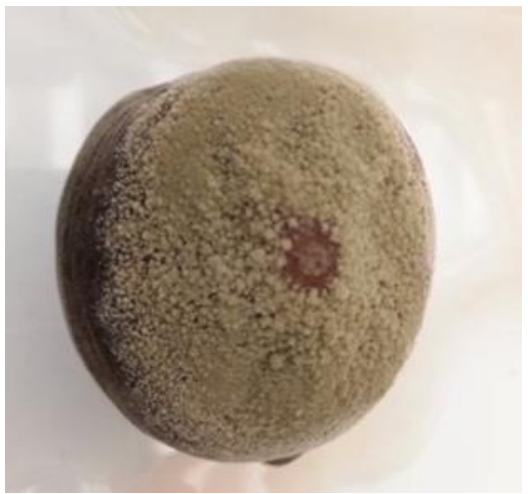

(b)

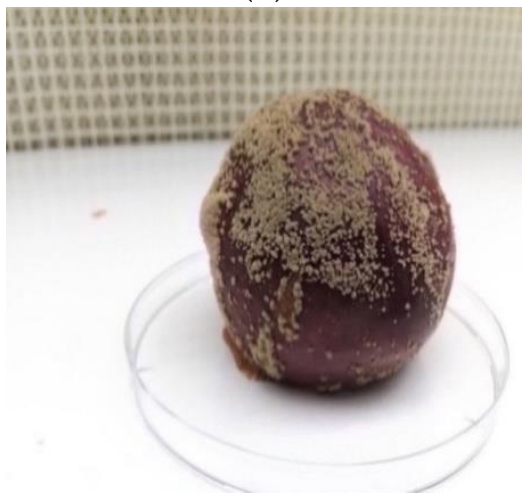

(d)

Figure 3. M. fructicola inoculum production and activation on peach (a) and M. laxa inoculum production and activation on peach, pear, and plum (b, $\mathbf{c}$, and $\mathbf{d}$, respectively) at 7 days postinoculation. The inoculated fruit, with $10 \mu \mathrm{L}$ at $10^{5}$ conidia $\mathrm{mL}^{-1}$ suspension concentration for each species, were incubated in a culture chamber at $24 / 18^{\circ} \mathrm{C}$ and $16 / 8 \mathrm{~h}$ light/dark photoperiods, in clear plastic boxes with maximized relative humidity.

For inoculum production, culture plates (i.e., V8A or PDA) are incubated between 20 and $25{ }^{\circ} \mathrm{C}$ under different photoperiods. Light is regarded as an essential promoter for conidium production. Authors have tried to produce inoculum under different photoperiods: $12 \mathrm{~h}$ light/dark or $16 \mathrm{~h}$ light/ $8 \mathrm{~h}$ dark; also, continuous light or dark were tested (Table 1), even though $M$. fructicola appeared to require shorter photoperiods than $M$. laxa to effectively sporulate [36], a $16 \mathrm{~h}$ light $/ 8 \mathrm{~h}$ dark photoperiod is based on our experience advisable to promote sporulation for both.

The time to promote sporulation of Monilinia Petri dish cultures is another phase that differs in literature. Depending on the type of medium and incubation condition, authors have used 5 to 14 days old cultures for inocula $[10,36,58,99]$. Though this period is critical, it should not exceed 14 days, especially for sporulation quality. 
Table 1. Phenotyping protocols for evaluating brown rot disease susceptibility in stone fruit.

\begin{tabular}{|c|c|c|c|c|c|c|c|c|c|c|}
\hline Fruit Species & Monilinia spp. & $\begin{array}{c}\text { Maturity } \\
\text { Determination }\end{array}$ & $\begin{array}{c}\text { Wounded or } \\
\text { Unwounded } \\
\text { (Intact) }\end{array}$ & $\begin{array}{l}\text { Production of } \\
\text { Inoculum }\end{array}$ & $\begin{array}{l}\text { Mode of } \\
\text { Inoculation }\end{array}$ & $\begin{array}{c}\text { Inoculum } \\
\text { Concentration } \\
\text { (conidia/mL) }\end{array}$ & Incubation Condition & Assessment Time & $\begin{array}{c}\text { Disease } \\
\text { Assessment }\end{array}$ & Reference \\
\hline Peach & M. fructicola & $\begin{array}{c}\text { Fruit color } \\
\text { determinations by } \\
\text { spectrophotome- } \\
\text { ter }\end{array}$ & $\begin{array}{l}\text { Unwounded, } \\
\text { wounded }\end{array}$ & V8A & Drop $10 \mu \mathrm{L}$ & $2.5 \times 10^{4}$ & $\begin{array}{l}\text { Humidified plastic } \\
\text { containers at room } \\
\text { temperature }\end{array}$ & 3 days & $\begin{array}{c}\text { Disease incidence, } \\
\text { disease severity } \\
\text { (lesion diameter) }\end{array}$ & [7] \\
\hline Peach & M. fructicola & $\begin{array}{l}\text { Mature (firm ripe) } \\
\text { and mature green }\end{array}$ & $\begin{array}{l}\text { Unwounded, } \\
\text { wounded }\end{array}$ & PDA & $\begin{array}{c}\text { Drop } 10 \mu \mathrm{L} \text { and a } \\
\text { 5-mm mycelial } \\
\text { disk }\end{array}$ & $2 \times 10^{5}$ & $\begin{array}{c}23-25^{\circ} \mathrm{C} / 90 \% \mathrm{RH} \text { in } \\
\text { dark }\end{array}$ & $\begin{array}{c}\text { (24, } 48 \text { and } 73,96 \\
\text { h), rote diameter } \\
(48,72 \text {, and } 96 \mathrm{~h}) \\
\text { and sporulation } 7 \\
\text { days }\end{array}$ & $\begin{array}{c}\text { Disease incidence, } \\
\text { disease severity } \\
\text { (rot diameter), } \\
\text { sporulation } \\
\text { amount }\end{array}$ & [47] \\
\hline Peach & M. fructicola & $\begin{array}{c}\text { Commercial } \\
\text { maturity }\end{array}$ & Unwounded & PDA & Drop $10 \mu \mathrm{L}$ & $2 \times 10^{4}$ & $\begin{array}{c}22-25{ }^{\circ} \mathrm{C} / 95 \% \mathrm{RH}, \text { in } \\
\text { dark }\end{array}$ & 3 days & Disease incidence & [46] \\
\hline $\begin{array}{l}\text { Peach, Nectarine, } \\
\text { Plum }\end{array}$ & M. fructicola & $\begin{array}{c}\text { Commercial } \\
\text { maturity }\end{array}$ & $\begin{array}{l}\text { Unwounded, } \\
\text { wounded }\end{array}$ & $\begin{array}{l}\text { PDA + acidified } \\
\text { lactic acid }\end{array}$ & Drop $20 \mu \mathrm{L}$ & $\begin{array}{c}1 \times 10^{6}, 10^{5}, 10^{4} \\
10^{3}, 10^{2}\end{array}$ & $\begin{array}{l}20^{\circ} \mathrm{C} / 95 \% \text { RH in } \\
\text { plastic cardboard boxes }\end{array}$ & 5 to 7 days & $\begin{array}{l}\text { Disease incident } \\
\text { and severity } \\
\text { (lesion diameter) }\end{array}$ & [57] \\
\hline Peach, Nectarine & M. fructicola & $\begin{array}{l}\text { Maturity classes } \\
\text { based on }\left(\mathrm{I}_{\mathrm{AD}}\right)\end{array}$ & $\begin{array}{l}\text { Unwounded, } \\
\text { wounded }\end{array}$ & $\begin{array}{c}\text { PDA } \\
\text { supplemented } \\
\text { with tomato pulp }\end{array}$ & Drop & $2.5 \times 10^{4}$ & $\begin{array}{l}20^{\circ} \mathrm{C} \text { and } 85 \% \mathrm{RH} \\
\text { storage boxes }\end{array}$ & 3 and 5 days & $\begin{array}{c}\text { Brown rot } \\
\text { incidence }(\%), \\
\text { lesion diameter }\end{array}$ & [11] \\
\hline Peach, Nectarine & $\begin{array}{l}\text { M. fructicola, } M \text {. } \\
\text { laxa }\end{array}$ & $\begin{array}{l}\text { Commercial } \\
\text { maturity }\end{array}$ & Wounded & PDA & Drop $15 \mu \mathrm{L}$ & $1 \times 10^{4}$ & $\begin{array}{c}0,4,10,15,20,25,30 \\
33^{\circ} \mathrm{C} \text { with } \pm 1{ }^{\circ} \mathrm{C} / 85 \% \\
\mathrm{RH}, \text { dark or } 12-\mathrm{h} \text { light } \\
\text { photoperiod }\end{array}$ & $\begin{array}{l}12 \mathrm{~h} \text { for } M \text {. } \\
\text { fructicola and } 5-7 \\
\text { days for M. laxa }\end{array}$ & $\begin{array}{l}\text { Lesion diameter, } \\
\text { presence or } \\
\text { absence of } \\
\text { sporodochia }\end{array}$ & [36] \\
\hline $\begin{array}{l}\text { Peach, Apricot, } \\
\text { Sweet cherry, } \\
\text { Plum }\end{array}$ & $\begin{array}{l}\text { M. fructicola, } M \text {. } \\
\text { laxa }\end{array}$ & $\begin{array}{l}\text { Commercial } \\
\text { maturity }\end{array}$ & Wounded & V8A & Drop $30 \mu \mathrm{L}$ & $1 \times 10^{5}$ & $\begin{array}{l}22^{\circ} \mathrm{C} / \text { high } \mathrm{RH} \text {, in } \\
\text { containers }\end{array}$ & 6 days & $\begin{array}{l}\text { Disease severity } \\
\text { (rot diameter) }\end{array}$ & [39] \\
\hline Peach, Nectarine & $\begin{array}{l}\text { M. fructicola, } M \text {. } \\
\text { laxa, M. fructigena }\end{array}$ & NA & Wounded & PDA & Drop $25 \mu \mathrm{L}$ & $1 \times 10^{4}$ & $\begin{array}{c}22 \pm 2{ }^{\circ} \mathrm{C} / \text { light and in } \\
\text { humidity chambers } \\
\text { lined with a moist } \\
\text { paper }\end{array}$ & 7 days & $\begin{array}{c}\text { \% brown rot } \\
\text { incidence, lesion } \\
\text { diameter, } \\
\text { sporulation, spore } \\
\text { germination, } \\
\text { mycelium length }\end{array}$ & [37] \\
\hline $\begin{array}{l}\text { Peach, Nectarine, } \\
\text { Apricot, Plum }\end{array}$ & $\begin{array}{l}\text { M. fructicola, } M . \\
\text { laxa }\end{array}$ & $\begin{array}{c}\text { Commercial } \\
\text { maturity, } \\
\text { immature fruit }\end{array}$ & $\begin{array}{l}\text { Unwounded, } \\
\text { wounded }\end{array}$ & V8A, PDA & $\begin{array}{c}\text { Filter paper disks } \\
\text { soaked in } \\
\text { suspension, drop } \\
10 \mu \mathrm{L}\end{array}$ & $1 \times 10^{4}$ & $\begin{array}{l}22-25^{\circ} \mathrm{C} /(90-100 \%) \text { in } \\
\text { plastic boxes lined with } \\
\text { a damp paper towel } \\
\text { and the lids closed }\end{array}$ & 7 days & $\begin{array}{l}\text { Pathogenicity and } \\
\text { disease incidence }\end{array}$ & [65] \\
\hline $\begin{array}{l}\text { Peach, Sweet } \\
\text { cherry }\end{array}$ & M. Fructicola & $\begin{array}{l}\text { Different maturity } \\
\text { date }\end{array}$ & Unwounded & PDA & Drop $30 \mu \mathrm{L}$ & $1 \times 10^{5}, 10^{6}$ & $\begin{array}{l}15 \text { to } 30^{\circ} \mathrm{C} \text { with } 2.5^{\circ} \mathrm{C} \\
\text { intervals, then at } \\
20^{\circ} \mathrm{C} />95 \% \mathrm{RH} \text {, in } \\
\text { plastic boxes }\end{array}$ & 6 days & $\begin{array}{c}\text { Disease severity } \\
\text { (scaling } 0 \text { to } 3 \text { ) and } \\
\text { percentage of fruit } \\
\text { infection }\end{array}$ & [35] \\
\hline
\end{tabular}


Table 1. Cont.

\begin{tabular}{|c|c|c|c|c|c|c|c|c|c|c|}
\hline Fruit Species & Monilinia spp. & $\begin{array}{c}\text { Maturity } \\
\text { Determination }\end{array}$ & $\begin{array}{l}\text { Wounded or } \\
\text { Unwounded } \\
\text { (Intact) }\end{array}$ & $\begin{array}{l}\text { Production of } \\
\text { Inoculum }\end{array}$ & $\begin{array}{l}\text { Mode of } \\
\text { Inoculation }\end{array}$ & $\begin{array}{l}\text { Inoculum } \\
\text { Concentration } \\
\text { (conidia/mL) }\end{array}$ & $\begin{array}{l}\text { Incubation } \\
\text { Condition }\end{array}$ & $\begin{array}{l}\text { Assessment } \\
\text { Time }\end{array}$ & $\begin{array}{c}\text { Disease } \\
\text { Assessment }\end{array}$ & Reference \\
\hline Peach & M. laxa & $\begin{array}{c}\text { Maturity at } 0.6 \\
\mathrm{I}_{\mathrm{AD}}\end{array}$ & Unwounded & NA & Spray & $1 \times 10^{5}$ & $\begin{array}{l}\text { Fruit left on the tree } \\
\text { bagged in plastic or } \\
\text { paper bags }\end{array}$ & 7 days & $\begin{array}{c}\text { Disease } \\
\text { incidence\% in } \\
\text { the field }\end{array}$ & [14] \\
\hline Peach & M. laxa & NA & Unwounded & NA & Spray & $1 \times 10^{5}$ & $\begin{array}{c}\text { at } 25 \pm \\
2{ }^{\circ} \mathrm{C} / 95-100 \% \mathrm{RH}\end{array}$ & 7 days & $\begin{array}{l}\text { Brown rot } \\
\text { infection } \\
\text { number, percent } \\
\text { of rotted skin } \\
\text { (lesion) }\end{array}$ & [50] \\
\hline Peach, Nectarine & M. laxa & NA & Unwounded & NA & $\begin{array}{l}\text { Sprayed to } \\
\text { runoff }\end{array}$ & $1 \times 10^{4}, 10^{6}$ & $\begin{array}{c}23^{\circ} \mathrm{C} / \text { in trays lined } \\
\text { with moist paper } \\
\text { and plastic film. } \\
16-\mathrm{h} \text { photoperiod }\end{array}$ & 7 days & $\begin{array}{l}\text { Incidence }(\%) \text { of } \\
\text { fruit rot }\end{array}$ & [4] \\
\hline Peach, Nectarine & M. laxa & $\begin{array}{l}\text { Optimum } \\
\text { maturity }\end{array}$ & $\begin{array}{l}\text { Unwounded, } \\
\text { wounded }\end{array}$ & Peach fruit & Drop & $25 \times 10^{3}$ & $\begin{array}{c}23^{\circ} \mathrm{C} / 40-60 \% \mathrm{RH}, \\
\text { in darkness }\end{array}$ & 5 days & $\begin{array}{c}\text { Measuring } \\
\text { brown rot } \\
\text { incidence }(\%), \\
\text { lesion diameter } \\
(\mathrm{mm}) \text { and } \\
\text { colonization } \\
\text { extent }(\mathrm{mm})\end{array}$ & [10] \\
\hline $\begin{array}{l}\text { Peach Apricot, } \\
\text { plum }\end{array}$ & M. laxa & $\begin{array}{l}\text { Commercial } \\
\text { maturity }\end{array}$ & $\begin{array}{l}\text { Unwounded, } \\
\text { wounded }\end{array}$ & Fruit & Drop $20 \mu \mathrm{L}$ & $1 \times 10^{6}$ & $23^{\circ} \mathrm{C} /$ high $\mathrm{RH}$ & $\begin{array}{c}10 \text { days } \\
\text { unwounded; } 5 \\
\text { days wounded }\end{array}$ & $\begin{array}{c}\text { Disease } \\
\text { incidence, } \\
\text { disease severity } \\
\text { (lesion } \\
\text { diameter) }\end{array}$ & [12] \\
\hline Peach, Apricot & M. laxa & $\begin{array}{l}\text { Commercial } \\
\text { maturity }\end{array}$ & $\begin{array}{l}\text { Unwounded, } \\
\text { wounded }\end{array}$ & V8A & $\begin{array}{l}\text { Dipping fruit for } \\
\text { (1 min) } \\
\text { inoculum }\end{array}$ & $1 \times 10^{5}$ & $20 \mathrm{C}$ and $95 \% \mathrm{RH}$ & 7 days & $\begin{array}{l}\text { Brown rot } \\
\text { incidence \% }\end{array}$ & [58] \\
\hline Peach, Plum & M. laxa & $\begin{array}{l}\text { Mature fruit } \\
\text { from the market }\end{array}$ & Wounded & $\begin{array}{l}\text { PDA, canned } \\
\text { peaches }\end{array}$ & $\begin{array}{l}\text { Dipping for } 30 \\
\text { sec in inoculum } \\
\text { suspension or a } \\
\text { drop }\end{array}$ & $\begin{array}{c}1 \times 10,10^{2}, 10^{3} \\
10^{4}, 10^{5} \\
\text { spore } / \mathrm{cm}^{3}\end{array}$ & $\begin{array}{l}21^{\circ} \mathrm{C} \text {, wrapped in } \\
\text { plastic bags }\end{array}$ & $\begin{array}{c}5 \text { days, or } 4 \text { to } 6 \\
\text { days }\end{array}$ & $\begin{array}{c}\text { Disease } \\
\text { incidence \% }\end{array}$ & [93] \\
\hline
\end{tabular}


Table 1. Cont.

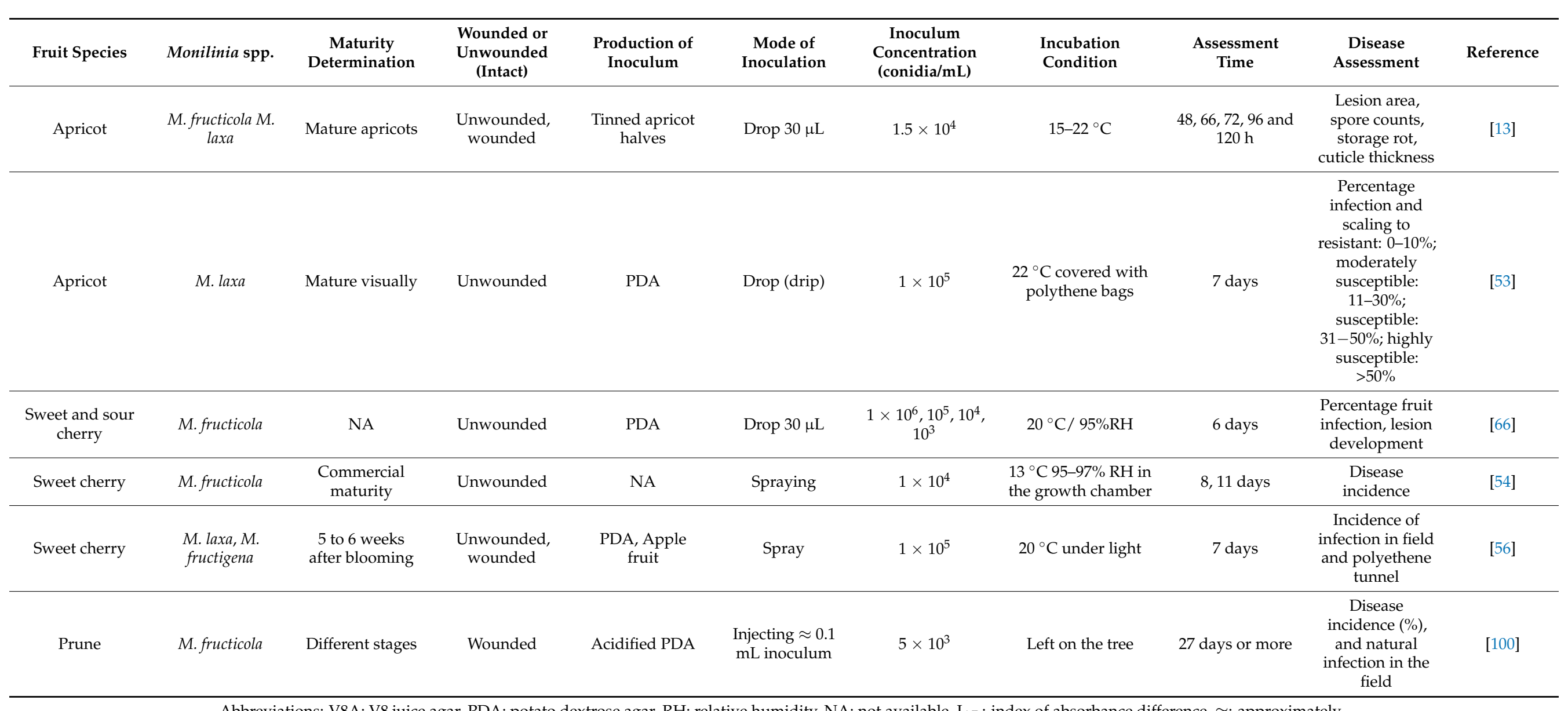

Abbreviations: V8A: V8 juice agar, PDA: potato dextrose agar, RH: relative humidity, NA: not available, $\mathrm{I}_{\mathrm{AD}}$ : index of absorbance difference, $\approx$ : approximately. 


\subsection{Inoculum Preparation}

Inoculum suspension is prepared by flooding the culture plates or washing-off fruit with distilled water and wetting agent such as Tween 20 or 80 at $0.01 \%$ [11] or $0.05 \%$ [58] to scrape the conidia. Vigorous shaking or centrifugation of the suspension is needed to break conidial chains, followed by filtering through different means to reduce the mycelium parts in the suspension as much as possible. Strainers with pore sizes ranging from 25 to $40 \mu \mathrm{m}$, or layers of cheesecloth or lens tissue, among others, could be used. Finally, conidium concentration in the suspension is evaluated by counting aliquots by a hemocytometer or other counting chambers; the suspension is then adjusted to the desired concentration.

In literature, inoculum concentration ranged from $10^{2}$ to $10^{6}$ conidia $\mathrm{mL}^{-1}$ depending on fruit ripening stage or integrity (intact or wounded). In the case of ripe fruit, concentrations from $10^{3}$ to $10^{5}$ conidia $\mathrm{mL}^{-1}$ should not be exceeded to highlight resistance, as applying a high inoculum pressure would lead to generalized infections.

Immature fruit require higher concentrations (around $10^{6}$ conidia $\mathrm{mL}^{-1}$ ) to obtain significant infections; the suggested level is probably the maximum that could occur in field conditions when fruit are ripe [66]. Hong et al. [57] demonstrated enlargement of lesion diameter with increased inoculum concentration in wounded peaches; simultaneously, a concentration of $10^{5}$ conidia $\mathrm{mL}^{-1}$ was required for unwounded fruit to obtain lesions around $10 \mathrm{~mm}$ diameter at 3-day post-inoculation. At lower concentrations (namely $10^{2}$, $10^{3}$, and $10^{4}$ conidia $\mathrm{mL}^{-1}$ ), fruit infections were delayed with significantly smaller lesion diameters. Overall, a concentration of $10^{5}$ conidia $\mathrm{mL}^{-1}$ appears to be an effective inoculum concentration, particularly for inoculating intact fruit.

\subsection{Field and Laboratory Protocols}

In general, protocols can be divided into two categories: protocols applied in the field (or in-situ) and laboratory.

Field protocols are intended to quickly screen a high number of trees through the artificial inoculation of tree-attached fruit. Very few protocols are available for field evaluation. Luo et al. [100] inoculated tree-attached plum fruit by injecting $100 \mu \mathrm{L}$ of M. fructicola conidia suspension at different growth stages and subsequently monitoring BR development. In a semi-field condition, $\mathrm{Xu}$ et al. [56] developed a protocol to evaluate the effect of fruit age and wetness duration on BR infection of tree-attached cherry fruit under polythene tunnel. A polythene bag was used to maintain adequate humidity; the inner side of the bag and the branch (including leaves and fruit) were wetted before inoculation by spraying distilled water. Then about $8 \mathrm{~mL}$ inoculum was sprayed onto the fruit on each branch until runoff, and then the polythene bag was placed over the branch and sealed with tape for different wetting periods before removing the bags.

More recently, in field conditions, Pacheco et al. [14] developed a protocol to screen large peach progenies in-situ to set up a more time- and cost-effective method to screen BR susceptibility in breeding programs.

Laboratory protocols provide a more accurate evaluation of the resistance displayed, although time-consuming as several steps are involved: fruit harvest, followed by preparation (as described in Section 3.1); arranging fruit in trays; inoculation, either on intact skin or after wounding in different ways. Inoculations by droplet or spray usually are practiced at different inoculum concentrations and incubation periods (see Section 3.7). Finally, observing fruit infection can be performed daily, and several indicators can be recorded (see Section 3.8). Both field and laboratory protocols have advantages and disadvantages (Table 2) and are contingent on the final objective and the quantity of material to be screened.

\subsection{Wounded or Unwounded Fruit}

Overall, injuring the fruit in the process of inoculation is a method to investigate the resistance of the flesh while infecting non-wounded fruit inspects the skin resistance. Since 
fruit skin is the first barrier to fungal invasion [11], the resistance of the flesh is expected to be low; therefore, most of the studies focus on non-wounded fruit.

Several authors comparatively studied wounded and unwounded artificial inoculations (Table 1). Generally, stone fruit are successfully infected by both wounded and non-wounded methods, except for plums that appeared to be infected only by wounding $[12,57,97]$.

Most of the studies show no correlation between skin and flesh resistance. As expected, unwounded fruit display less susceptibility, suggesting that most of the resistance lies in the skin $[7,11,12,47,48,80,101]$. Conversely, Mari et al. [58] observed a correlation between susceptibility of wounded and unwounded fruit in peach and apricot: they explained the results in light of a typical biochemical response of both skin and flesh. Finally, as evident in almost all literature, wounding deprives the fruit of its main barrier against pathogens [56,57], resulting in higher infection and severity levels compared to intact fruit.

Table 2. Advantages and disadvantages of field and laboratory-based protocols to evaluate fruit resistance level.

\begin{tabular}{|c|c|c|c|}
\hline Evaluating Environments & Advantages & Disadvantages & References \\
\hline Field & $\begin{array}{l}\text { Relatively faster in manipulation. } \\
\text { Plenty of accessions can be evaluated in } \\
\text { a short time. }\end{array}$ & $\begin{array}{c}\text { High variability, which may } \\
\text { lead to low repeatability of the } \\
\text { result. } \\
\text { Environmental factors may } \\
\text { impair the level of the } \\
\text { recorded susceptibility. }\end{array}$ & {$[14,99]$} \\
\hline $\begin{array}{l}\text { Laboratory or controlled } \\
\text { condition }\end{array}$ & $\begin{array}{c}\text { Enables fruit preparation before } \\
\text { inoculation, such as disinfection, } \\
\text { wounding. } \\
\text { Facilitates the post-inoculation } \\
\text { evaluation of traits such as fruit weight, } \\
\text { acidity, Brix. } \\
\text { Provides repeatable environmental } \\
\text { conditions. } \\
\text { Fruit manipulations relatively easier. } \\
\text { Inoculum load could be precisely } \\
\text { placed on fruit sides (cheeks). } \\
\text { Allows recording of many parameters. }\end{array}$ & $\begin{array}{l}\text { Not exactly representing the } \\
\text { natural (field) condition. } \\
\text { It is more laborious. }\end{array}$ & {$[7,55,102]$} \\
\hline
\end{tabular}

\subsection{Artificial Inoculum Application}

Several methods have been used in artificial fruit inoculation, e.g., spraying, dropping, injecting, dipping. However, a comprehensive comparison among different methods is still lacking. Techniques are chosen based on their applicability and reliability in coherence with the whole protocol. For instance, spraying until inoculum runoff is mainly used in the field since other methods are difficult to apply on a tree-hanging fruit. Above all, this approach probably imitates the best way in which inoculum naturally arrives at multi-points on fruit in the field, via splashing $[14,56,103]$.

In the laboratory, droplet fruit inoculation, dipping fruit in suspension, and fruit spraying are the main methods used for non-wounding fruit inoculation. On the other hand, some other methods are mainly used for applying inoculum to wounded fruit, such as placing or directly injecting an inoculum droplet and attaching an active mycelium plug to the wound (Table 1). The wounds can be made by inserting a disinfected needle or a sharp blade into the fruit peel. However, for both wounded and non-wounded, the position and amount of the inoculum are important and should be well maintained. The fruit cheeks are frequently chosen to deposit the drop inoculum, regardless of being wounded or non-wounded. At maturity, cheeks are considered the least susceptible fruit part to microcracking compared to suture, pedicel cavity, and stylar region, as reported for nectarine [71] and cherry fruit [104,105]. Some authors have explicitly considered 
the position of depositing the inoculum droplet on the red (or sun-exposed) cheek $[8,11]$. The suspension amount per droplet may range from 10 to $30 \mu \mathrm{L}$ regardless of inoculum concentration. Inoculation by paper disks soaked in a suspension of conidia and then laid on the fruit is a less common method [65]. Furthermore, non-ionic polysorbate such as Tween 20 or 80 at low concentrations from $0.005 \%$ to $0.05 \%$ is often added to the suspension $[10,13,14,95]$, as surfactant (wetting agent) in conidial suspension. Its effects and functions have been widely studied on the inoculum preparation and viability of fungal biocontrol agents $[101,106,107]$. However, the influence of those surfactants on Monilinia has not been particularly addressed.

\subsection{Incubation}

Incubation is the time that Monilinia spp. requires to colonize inoculated fruit and display visible symptoms. However, this period may vary depending on the method of inoculation. For example, the time required to show the infection is shorter on wounded than non-wounded fruit; for peach, only two days are needed, while for plum, it takes four days [57]. Baró-Montel et al. [11] have measured lesion diameter at 3-7 days postinoculation and observed a significant increase in lesion diameter in wounded fruit at 4 to 6 days post-inoculation. In contrast, for non-wounded fruit, the measurements were delayed up to seven days. Overall, most authors have considered seven days as an appropriate incubation period (Table 1).

Similarly, inoculated fruit can be incubated under the same conditions described in Section 3.2. Regardless of the stone fruit species, a diverse range of temperatures and humidity was used. However, predominantly inoculated fruit are incubated at ranges of $20-25^{\circ} \mathrm{C}$ and $85-100 \% \mathrm{RH}$ in a growth chamber or arranged in plastic boxes to secure the high relative humidity. On few occasions, fruit were incubated at lower humidity of 40-60\% $\mathrm{RH}$, which might not be optimal (Table 1). Furthermore, inoculated fruit are incubated at different photoperiods, such as continuous light or dark, and 12/12 h or 16/8 h light/dark photoperiods (Table 1). Since Monilinia spp. can successfully infect stone fruit at different light conditions, setting a photoperiod seems more reasonable. For example, $58 \mathrm{~W}$ white light in a 12/12 h light/dark cycle increased disease severity and sporulation more than continuous darkness in inoculated nectarines with M. laxa, while different photoperiods did not affect BR incidence [102].

\subsection{Infection Assessment}

Infection assessment is the final step of the phenotyping methodology when the state of infection is assessed and recorded. Two main variables are predominantly used: disease incidence and disease severity.

The disease incidence calculated as the number of infected fruits out of total inoculated. When the assessment is carried out in the field, this is the only available variable since no time follow-up is possible. Notably, disease incidence is the only variable recorded in cherry since measuring the progress of lesion diameter is difficult, given the small size of the fruit (Table 1).

The disease severity is estimated as the mean of lesion diameter or area, originated from inoculum point on the fruit surface. This is easier to record when only a single drop is deposited on the fruit, which is an indicator of the rapidity of the disease advancement (Table 1). Hong et al. [57] have not accounted for lesions that did not originate from the inoculation points since they were considered a natural infection. Furthermore, Biggs and Northover [35] have transformed the disease severity of unwounded peach and sweet cherry fruit inoculated with $M$. fructicola to a scale of 0 to 3 , where $0=$ no visible infection; $1=$ necrosis not wider than the inoculum drop; $2=$ necrosis wider than the width of the inoculum drop, but without sporodochia; and 3 = sporodochia present on the necrotic lesion.

Notably, BR development may be delayed in non-wounded compared to wounded fruit treatments [13]. In addition, a delay of lesion appearance and severity reduction is 
reported when inoculum concentrations were lowered from $4 \times 10^{4}$ to $5 \times 10^{2}$ conidia $\mathrm{mL}^{-1}$ [103]. Consequently, for both cases, Monilinia spp. required more time to penetrate and develop on fruit.

In our lab, nine individuals of an interspecific peach progeny called $\mathrm{BC} 2$ were characterized through laboratory infection. We further took advantage of lesion diameter recording over time to investigate additional indicators in infection assessment, namely, the delay before infection and the speed of lesion appearance, which could be calculated from observed lesion profiles. The infection delay is considered as the time between drop deposit to the lesion formation (incubation period) by the naked eye, while the speed of lesion development was calculated as the maximum increase in lesion diameter in $\mathrm{mm} /$ hour. The infection diameter was calculated as the lesion diameter $(\mathrm{mm})$ average recorded three days after infection.

The results exhibited distinctive variations between individuals and years of observations (2013 and 2014) (Figure 4). For most individuals, BR lesions were observed after $72 \mathrm{~h}$ (3 days). However, one accession particularly and to a lesser extent in addition to the infection was much more delayed or never occurred in many fruits, probably due to resistance factors at the skin level.

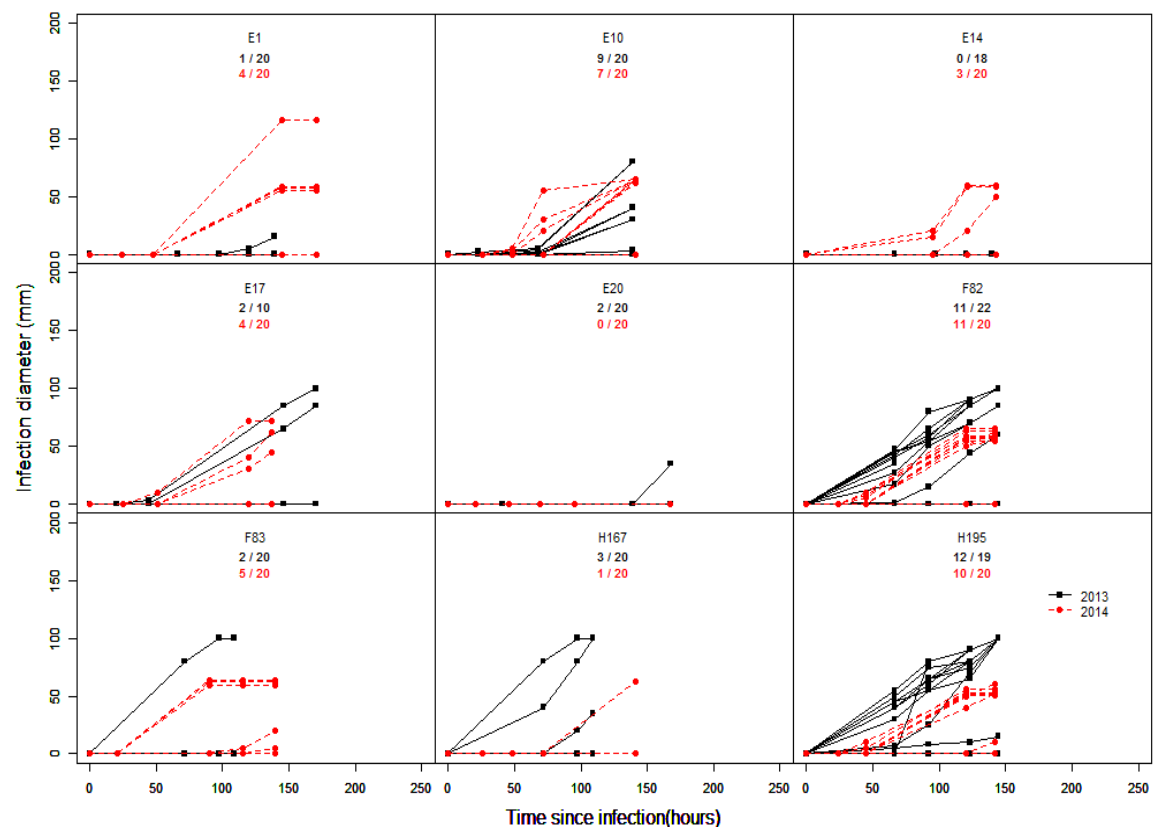

Figure 4. Development of lesion diameter $(\mathrm{mm})$ in infected fruit. Intact fruit were inoculated with a droplet of $10 \mu \mathrm{L}$ M. laxa at $10^{5}$ conidia $\mathrm{mL}^{-1}$ concentration over two years. Each curve represents an infected fruit out of 20 inoculated (infected/total inoculated) fruits for nine genotypes (black curves: 2013; red curves: 2014). Inoculated fruit were incubated in clear plastic boxes with maximized relative humidity for seven days.

Regarding the lesion diameter and the speed of lesion development, they might be considered as linked to flesh resistance. These indicators scored on progenies or in germplasm collections can be regarded as quantitative traits and used in genetic analyses to explore trait-markers relationships.

\section{Inconsistency of Infection Results}

In plant biology, phenotypic instability is sometimes considered a form of plasticity in response to variations in environmental factors such as nutrients, water availability, and temperature [108]. Likewise, several hosts and related environmental factors may cause phenotyping inconsistency, in particular across years or methodologies. Pacheco et al. [8] noticed an inversion of the behavior of the two accessions 'Contender' and 'Elegant Lady' 
for BR diameter between 2009 and 2010. In contrast, Martínez-García et al. [7] reported general consistency in ranking within a peach progeny over the three seasons tested. However, variation in resistance or susceptibility between two years was also reported.

Therefore, we further investigate the inconsistency of evaluation across years and methodologies in both orchard (field) and laboratory, including naturally occurring infections. The experiment was carried out on fruit of P. davidiana and P. persica cv Summergrand [109] for three consecutive years (2013, 2014, and 2015). A single-spore isolate of $M$. laxa (Ml3) at $10^{5}$ conidia $\mathrm{mL}^{-1}$ inoculum concentration was used throughout the experiment. Mature fruit were inoculated by spraying in the field or applying a drop of $10 \mu \mathrm{L}$ inoculum in the lab. Depending on the year, the genotypes were not stable in terms of susceptibility, regardless of the infection methodology. Low correlations were observed between years 2013 vs. 2014 and 2014 vs. 2015 in the field and between 2013 and 2014 in the laboratory. The best correlation was found in 2015 for the field vs. lab trials when inoculum spray was used. Additionally, field vs. natural infection was also significantly correlated in the year 2015 (Table 3).

Table 3. Correlation of brown rot disease incidence between years and different tests: lab and field inoculations were performed using drop and spray, respectively.

\begin{tabular}{ccc}
\hline Inoculation Test & Correlation & $p$-Value \\
\hline field 2013 vs. field 2014 & 0.2861 & $0.0063^{*}$ \\
\hline field 2013 vs. field 2015 & -0.0819 & 0.5004 \\
\hline field 2014 vs. field 2015 & 0.3148 & $0.003^{*}$ \\
\hline lab 2013 vs. lab 2014 & 0.288 & $0.003^{*}$ \\
\hline lab 2013 vs. lab 2015 ${ }^{1}$ & -0.0292 & 0.8162 \\
\hline lab 2014 vs. lab 2015 ${ }^{1}$ & 0.2401 & 0.0522 \\
\hline field 2013 vs. lab 2013 & 0.2947 & $0.0056^{*}$ \\
\hline field 2013 vs. lab 2014 & -0.1151 & 0.3123 \\
\hline field 2013 vs. lab 2015 & 0.7223 \\
\hline field 2014 vs. lab 2014 & 0.049 & 0.0884 \\
\hline field 2014 vs. lab 2015 ${ }^{1}$ & 0.1704 & 0.1509 \\
\hline field 2015 vs. lab 2015 ${ }^{1}$ & 0.2301 & $10^{-4 * * *}$ \\
\hline field 2015 vs. natural infection 2015 & 0.4562 & $10^{-4 * * *}$ \\
\hline
\end{tabular}

${ }^{1}$ In 2015, lab inoculation was performed by spray. ${ }^{* * *}$ Significant differences at $p$ value $<0.0001,{ }^{*}$ Significant differences at $p$ value $<0.01$.

In artificial infection in the field, environmental factors may be involved in this phenotypic diversity even though paper bags were used to maintain high humidity and favor infection [14]. The controlled inoculation mitigated the increased risk of infection, which is often observed as the season progresses. Interestingly, no correlation was found between the infection probability in the orchard and the different environmental factors (i.e., minimal and maximal temperature, moisture, wind velocity) (data not shown). As mentioned above, many factors related to fruit growing conditions, horticultural practices, and weather can be involved in such instability and are difficult to be accounted for. In the case of 'lab' tests, the year effect is complicated to explain, as usually this approach is supposed to control for several factors. Fruit developmental and growth conditions in the orchard undoubtedly play a significant role in this observed instability. For example, the status of the skin is essential, and perhaps the drop is sometimes deposited on microcracks not visible to the naked eye. 


\section{Conclusions}

Phenotyping is a crucial step in breeding stone fruit for brown rot resistance. Monilinia spp. are necrotrophic fungi requiring several factors to infect stone fruit successfully. In the early stages of fruit development, success primarily depends on pathogen inocula and environmental conditions. Subsequently, other crop-related factors such as cultivar, fruit-related traits, and development stage, and field management practices play a significant role in BR development. As the main barrier to infection, fruit skin characteristics seem to be critical, also considering that microcracks and natural openings are the main entrance points of the pathogen. Despite many efforts initiated in breeding programs, more obviously for peaches and nectarines, no truly BR-resistant stone fruit cultivars are commercially available. While further attempts and contributions by stone fruit breeders are expected, the first step to success relies on the optimization of the phenotyping protocols. This literature review highlights the variability in applied procedures and non-consensus methodologies. All steps of the phenotyping protocol are crucial to ensure suitable infection performance, from fruit sampling to inoculum preparation and application. Fruit preparation before inoculation requires utmost attention: for example, when the natural pathogen pressure in the orchards is not too high, the best advice is not to disinfect fruit before inoculation. Furthermore, injuring the fruit seems to be a dead-end since an infection that has reached the flesh no longer stops. Moreover, the choice between spray in orchard and inoculum droplet in the lab lies in the objectives of the test and other variables to record and phenotyping capacity (workforce). Finally, it seemed that inoculum droplet and spray tests do not provide the same information regarding fruit susceptibility. Overall, even taking all possible precautions discussed, inconsistency could be expected, and multi-year assays are highly recommended to gather valuable results.

Author Contributions: Conceptualization, B.Q.-T. and M.H.M.; methodology and formal analysis, M.-N.C., L.O.L. and V.S.; investigation, M.H.M.; writing-original draft preparation, M.H.M. and L.O.L.; writing-review and editing, D.B., B.Q.-T. and M.C. All authors have read and agreed to the published version of the manuscript.

Funding: This research is in the framework of FREECLIMB_Fruit Crops Resilience To Climate Change In The Mediterranean Basin, PRIMA network, \#1813-2, and funded by the Italian Ministry of University, Decree 1441 on 16 September 2020.

Institutional Review Board Statement: Not applicable.

Informed Consent Statement: Not applicable.

Data Availability Statement: Data available on request from the corresponding author.

Conflicts of Interest: The authors declare no conflict of interest.

\section{References}

1. Byrde, R.J.W.; Willetts, H.J. The Brown Rot Fungi of Fruit: Their Biology and Control; Pergamon Press: Oxford, UK, 1977.

2. Larena, I.; Torres, R.; De Cal, A.; Liñán, M.; Melgarejo, P.; Domenichini, P.; Bellini, A.; Mandrin, J.F.; Lichou, J.; De Eribe, X.O.; et al. Biological control of postharvest brown rot (Monilinia spp.) of peaches by field applications of Epicoccum nigrum. Biol. Control 2005, 32, 305-310. [CrossRef]

3. Hong, C.; Michailides, T.J. Effect of Temperature on the Discharge and Germination of Ascospores by Apothecia of Monilinia fructicola. Plant Dis. 1998, 82, 195-202. [CrossRef] [PubMed]

4. Gell, I.; De Cal, A.; Torres, R.; Usall, J.; Melgarejo, P. Relationship between the incidence of latent infections caused by Monilinia spp. and the incidence of brown rot of peach fruit: Factors affecting latent infection. Eur. J. Plant Pathol. 2008, 121, 487-498. [CrossRef]

5. Chen, F.; Liu, X.; Chen, S.; Schnabel, E.; Schnabel, G. Characterization of Monilinia fructicola Strains Resistant to Both Propiconazole and Boscalid. Plant Dis. 2013, 97, 645-651. [CrossRef] [PubMed]

6. Egüen, B.; Melgarejo, P.; De Cal, A. Sensitivity of Monilinia fructicola from Spanish peach orchards to thiophanate-methyl, iprodione, and cyproconazole: Fitness analysis and competitiveness. Eur. J. Plant Pathol. 2015, 141, 789-801. [CrossRef]

7. Martínez-García, P.J.; Parfitt, D.E.; Bostock, R.M.; Fresnedo-Ramírez, J.; Vazquez-Lobo, A.; Ogundiwin, E.A.; Gradziel, T.M.; Crisosto, C.H. Application of genomic and quantitative genetic tools to identify candidate resistance genes for brown rot resistance in peach. PLoS ONE 2013, 8, e78634. [CrossRef] [PubMed] 
8. Pacheco, I.; Bassi, D.; Eduardo, I.; Ciacciulli, A.; Pirona, R.; Rossini, L.; Vecchietti, A. Qtl mapping for brown rot (Monilinia fructigena ) resistance in an intraspecific peach (Prunus persica L. Batsch) F1 progeny. Tree Genet. Genomes 2014, 10, 1223-1242. [CrossRef]

9. Baró-Montel, N.; Eduardo, I.; Usall, J.; Casals, C.; Arús, P.; Teixidó, N.; Torres, R. Exploring sources of resistance to brown rot in an interspecific almond $\times$ peach population. J. Sci. Food Agric. 2019, 99, 4105-4113. [CrossRef] [PubMed]

10. Obi, V.I.; Barriuso, J.J.; Moreno, M.A.; Giménez, R.; Gogorcena, Y. Optimizing protocols to evaluate brown rot (Monilinia laxa) susceptibility in peach and nectarine fruits. Australas. Plant Pathol. 2017, 46, 183-189. [CrossRef]

11. Baró-Montel, N.; Torres, R.; Casals, C.; Teixidó, N.; Segarra, J.; Usall, J. Developing a methodology for identifying brown rot resistance in stone fruit. Eur. J. Plant Pathol. 2019, 154, 287-303. [CrossRef]

12. Pascal, T.; Levigneron, A.; Kervella, J.; Nguyen-The, C. Evaluation of two screening methods for resistance of apricot, plum and peach to Monilinia laxa. Euphytica 1994, 77, 19-23. [CrossRef]

13. Walter, M.; McLaren, G.F.; Fraser, J.A.; Frampton, C.M.; Boyd-Wilson, K.S.H.; Perry, J.H. Methods of screening apricot fruit for resistance to brown rot caused by Monilinia spp. Australas. Plant Pathol. 2004, 33, 541-547. [CrossRef]

14. Pacheco, I.; Perini, C.; Bassi, D.; Lama, M.; Foschi, S. Towards faster phenotyping methods for brown rot susceptibility by artificial inoculation in the orchard. In Proceedings of the VIII International Peach Symposium, Matera, Italy, 17-20 June 2013; Volume 1084, pp. 367-373.

15. Ogawa, J.M.; Zehr, E.I.; Biggs, A.R. Brown rot. In Compendium of Stone Fruit Disease; Ogawa, J.M., Zehr, E.I., Bird, G.W., Ritchie, D.F., Uriu, K., Uyemoto, J.K., Eds.; American Phytopathological Society: Saint Paul, MN, USA, 1995; pp. 7-10.

16. Jerome, S.M.R. Brown rot of stone fruits. Latent contamination in relation to spread of disease. J. Aust. Inst. Agric. Sci. 1958, 24, 132-140.

17. Holtz, B.A.; Michailides, T.J.; Hong, C. Development of apothecia from stone fruit infected and stromatized by Monilinia fructicola in California. Plant Dis. 1998, 82, 1375-1380. [CrossRef]

18. Biggs, A.R.; Northover, J. Inoculum sources for Monilinia fructicola in Ontario peach orchards. Can. J. Plant Pathol. 1985, 7, 302-307. [CrossRef]

19. Gell, I.; De Cal, A.; Torres, R.; Usall, J.; Melgarejo, P. Conidial density of Monilinia spp. on peach fruit surfaces in relation to the incidences of latent infections and brown rot. Eur. J. Plant Pathol. 2009, 123, 415-424. [CrossRef]

20. Casals, C.; Segarra, J.; De Cal, A.; Lamarca, N.; Usall, J. Overwintering of Monilinia spp. on mummified stone fruit. J. Phytopathol. 2015, 163, 160-167. [CrossRef]

21. Landgraf, F.A.; Zehr, E.I. Inoculum sources for Monilinia fructicola in South Carolina peach orchards. Phytopathology 1982, 72, 185-190. [CrossRef]

22. Villarino, M.; Melgarejo, P.; Usall, J.; Segarra, J.; De Cal, A. Primary inoculum sources of Monilinia spp. in Spanish peach orchards and their relative importance in brown rot. Plant Dis. 2010, 94, 1048-1054. [CrossRef] [PubMed]

23. Northover, J.; Cerkauskas, R.F. Detection and significance of symptomless latent infections of Monilinia fructicola in plums. Can. J. Plant Pathol. 1994, 16, 30-36. [CrossRef]

24. Garcia-benitez, C.; Casals, C.; Usall, J.; Ismael, S.; Sánchez-Ramos, I.; Melgarejo, P.; De Cal, A. Impact of Postharvest Handling on Preharvest Latent Infections Caused by Monilinia spp. in Nectarines. J. Fungi 2020, 6, 266. [CrossRef] [PubMed]

25. Förster, H.; Adaskaveg, J.E. Early brown rot infections in sweet cherry fruit are detected by Monilinia-specific DNA primers. Phytopathology 2000, 90, 171-178. [CrossRef] [PubMed]

26. Adaskaveg, J.E.; Schnabel, G.; Förster, H. Diseases of Peach Caused by Fungi and Fungal-Like Organisms: Biology, Epidemiology and Management; CABI: Wallingford, UK, 2008; pp. 352-406.

27. Agrios, G.N. Plant Pathology, 5th ed.; Elsevier: San Diego, CA, USA, 2005. [CrossRef]

28. Lopresti, J.; Goodwin, I.; McGlasson, B.; Holford, P.; Golding, J. Variability in size and soluble solids concentration in peaches and nectarines. Hortic. Rev. (Am. Soc. Hortic. Sci). 2014, 42, 253-311.

29. Lee, M.-H.H.; Bostock, R.M. Induction, regulation, and role in pathogenesis of appressoria in Monilinia fructicola. Phytopathology 2006, 96, 1072-1080. [CrossRef] [PubMed]

30. De Oliveira Lino, L.; Génard, M.; Signoret, V.; Quilot-Turion, B. Physical host factors for brown rot resistance in peach fruit. Acta Hortic. 2016, 1137, 105-112. [CrossRef]

31. Cruickshank, R.H.; Wade, G.C. The activation of latent infections of Monilinia fructicola on apricots by volatiles from the ripening fruit. J. Phytopathol. 1992, 136, 107-112. [CrossRef]

32. Willetts, H.J.; Harada, Y. A review of apothecial production by Monilinia fungi in Japan. Mycologia 1984, 76, 314-325. [CrossRef]

33. Weaver, L.O. Effect of temperature and relative humidity on occurrence of blossom blight of stone fruits. Phytopathology 1950, 40, 1136-1153.

34. McCallan, S.E.A. Studies on fungicides. II. Testing protective fungicides in the laboratory. Cornell Univ. Agric. Exp. Stn. Man. 1930, 128, 14 .

35. Biggs, A.R.; Northover, J. Influence of temperature and wetness duration on infection of peach and sweet cherry fruits by Monilinia fructicola. Phytopathology 1988, 78, 1352. [CrossRef]

36. Bernat, M.; Segarra, J.; Xu, X.-M.M.; Casals, C.; Usall, J. Influence of temperature on decay, mycelium development and sporodochia production caused by Monilinia fructicola and M. laxa on stone fruits. Food Microbiol. 2017, 64, 112-118. [CrossRef] [PubMed] 
37. Villarino, M.; Melgarejo, P.; De Cal, A. Growth and aggressiveness factors affecting Monilinia spp. survival peaches. Int. J. Food Microbiol. 2016, 227, 6-12. [CrossRef] [PubMed]

38. Bernat, M.; Casals, C.; Torres, R.; Teixidó, N.; Usall, J. Infection risk of Monilinia fructicola on stone fruit during cold storage and immersion in the dump tank. Sci. Hortic. 2019, 256, 108589. [CrossRef]

39. Papavasileiou, A.; Testempasis, S.; Michailides, T.J.; Karaoglanidis, G.S. Frequency of brown rot fungi on blossoms and fruit in stone fruit orchards in Greece. Plant Pathol. 2015, 64, 416-424. [CrossRef]

40. Wellman, R.H.; McCallan, S.E.A. An analysis of factors causing variation in spore germination tests of fungicides. IV. Time Temp. Contrib. Boyce Thompson Inst 1942, 12, i1.

41. Tamm, L.; Minder, C.E.; Fluckiger, W.; Minder, E.; Fluckiger, W. Phenological analysis of brown rot blossom blight of sweet cherry caused by Monilinia laxa. Phytopathology 1995, 85, 401-408. [CrossRef]

42. Fourie, P.H.; Holzh, G. Germination of dry, airborne conidia of Monilinia laxa and disease expression on nectarine fruit. Australas. Plant Pathol. 2003, 32, 9-18. [CrossRef]

43. Corbin, J.B.; Ogawa, J.M.; Schultz, H.B. Fluctuations in numbers of Monilinia laxa conidia in an apricot orchard during the 1966 season. Phytopathology 1968, 58, 1387.

44. Holb, I.J. The brown rot fungi of fruit crops (Monilinia spp.): II. Important features of their epidemiology (Review paper). Int. J. Hortic. Sci. 2004, 10, 31-49. [CrossRef]

45. Rungindamai, N.; Jeffries, P.; Xu, X.M. Epidemiology and management of brown rot on stone fruit caused by Monilinia laxa. Eur. J. Plant Pathol. 2014, 140,1-17. [CrossRef]

46. Gradziel, T.M.; Thorpe, M.A.; Bostock, R.M.; Wilcox, S. Breeding for brown rot (Monilinia fructicola) resistance in clingstone peach with emphasis on the role of fruit phenolics. Acta Hortic. 1998, 465, 161-170. [CrossRef]

47. Feliciano, A.; Feliciano, F.A.; Ogawa, J.M. Monilinia fructicola Resistance in the Peach Cultivar Bolinha. Phytopathology 1987, 77, 776. [CrossRef]

48. Bostock, R.M.; Wilcox, S.M.; Wang, G.; Adaskaveg, J.E. Suppression of Monilinia fructicola cutinase production by peach fruit surface phenolic acids. Physiol. Mol. Plant Pathol. 1999, 54, 37-50. [CrossRef]

49. Baccichet, I.; Chiozzotto, R.; Bassi, D.; Gardana, C.; Cirilli, M.; Spinardi, A. Characterization of fruit quality traits for organic acids content and profile in a large peach germplasm collection. Sci. Hortic. 2021, 278, 109865. [CrossRef]

50. Bassi, D.; Rizzo, M.; Cantoni, L. Assaying brown rot [(Monilinia laxa Aderh. et Ruhl. (Honey)] susceptibility in peach cultivars and progeny. Acta Hortic. 1998, 465, 715-721. [CrossRef]

51. Brown, A.F.; Yousef, G.G.; Guzman, I.; Chebrolu, K.K.; Werner, D.J.; Parker, M.; Gasic, K.; Perkins-Veazie, P. Variation of carotenoids and polyphenolics in peach and implications on breeding for modified phytochemical profiles. J. Am. Soc. Hortic. Sci. 2014, 139, 676-686. [CrossRef]

52. Fu, W.; Burrell, R.; Linge, C.d.S.; Schnabel, G.; Gasic, K. Breeding for brown rot (Monilinia spp.) tolerance in Clemson University peach breeding program. J. Am. Pomol. Soc. 2018, 72, 94-100.

53. Nicotra, A.; Conte, L.; Moser, L.; Fantechi, P.; Barbagiovanni, I.; Corazza, L.; Vitale, S.; Magnotta, A. Breeding programme for Monilinia laxa (Aderh. et Ruhl.) resistance on apricot. Acta Hortic. 2006, 701, 307-311. [CrossRef]

54. Kappel, F.; Sholberg, P.L. Screening sweet cherry cultivars from the Pacific Agri-Food Research Centre Summerland breeding program for resistance to brown rot (Monilinia fructicola). Can. J. Plant Sci. 2008, 88, 747-752. [CrossRef]

55. Northover, J.; Biggs, A.R. Effect of conidial concentration of Monilinia fructicola on brown rot development in detached cherries. Can. J. Plant Pathol. 1995, 17, 205-214. [CrossRef]

56. Xu, X.M.; Bertone, C.; Berrie, A. Effects of wounding, fruit age and wetness duration on the development of cherry brown rot in the UK. Plant Pathol. 2007, 56, 114-119. [CrossRef]

57. Hong, C.; Michailides, T.J.; Holtz, B.A. Effects of wounding, inoculum density, and biological control agents on postharvest brown rot of stone fruits. Plant Dis. 1998, 82, 1210-1216. [CrossRef] [PubMed]

58. Mari, M.; Casalini, L.; Baraldi, E.; Bertolini, P.; Pratella, G.C. Susceptibility of apricot and peach fruit to Monilinia laxa during phenological stages. Postharvest Biol. Technol. 2003, 30, 105-109. [CrossRef]

59. Luo, Y.; Michailides, T.J. Factors Affecting Latent Infection of Prune Fruit by Monilinia fructicola. Phytopathology 2001, 91, 864-872. [CrossRef] [PubMed]

60. Oliveira Lino, L.; Quilot-Turion, B.; Dufour, C.; Corre, M.-N.; Lessire, R.; Génard, M.; Poëssel, J.-L. Cuticular waxes of nectarines during fruit development in relation to surface conductance and susceptibility to Monilinia laxa. J. Exp. Bot. 2020. [CrossRef] [PubMed]

61. Thomidis, T.; Tsipouridis, C.; Darara, V. Seasonal variation of nutrient elements in peach fruits (cv. May Crest) and its correlation with development of Brown rot (Monilinia laxa). Sci. Hortic. 2007, 111, 300-303. [CrossRef]

62. Curtis, K.M. The morphological aspect of resistance to brown rot in stone fruit. Ann. Bot. 1928, 42, 39-68. [CrossRef]

63. Emery, K.M.; Michailides, T.J.; Scherm, H. Incidence of latent infection of immature peach fruit by Monilinia fructicola and relationship to brown rot Georgia. Plant Dis. 2000, 84, 853-857. [CrossRef]

64. Guidarelli, M.; Zubini, P.; Nanni, V.; Bonghi, C.; Rasori, A.; Bertolini, P.; Baraldi, E. Gene expression analysis of peach fruit at different growth stages and with different susceptibility to Monilinia laxa. Eur. J. Plant Pathol. 2014, 140, 503-513. [CrossRef]

65. Kreidl, S.; Edwards, J.; Villalta, O.N. Assessment of pathogenicity and infection requirements of Monilinia species causing brown rot of stone fruit in Australian orchards. Australas. Plant Pathol. 2015, 44, 419-430. [CrossRef] 
66. Northover, J.; Biggs, A.R. Susceptibility of immature and mature sweet and sour cherries to Monilinia fructicola. Plant Dis. 1990, 74, 280. [CrossRef]

67. Li, S.-H.; Huguet, J.-G.; Schoch, P.G.; Orlando, P. Response of peach tree growth and cropping to soil water deficit at various phenological stages of fruit development. J. Hortic. Sci. 1989, 64, 541-552. [CrossRef]

68. Luo, Y.; Ma, Z.; Michailides, T.J. Analysis of factors affecting latent infection and sporulation of Monilinia fructicola on prune fruit. Plant Dis. 2001, 85, 999-1003. [CrossRef] [PubMed]

69. Mercier, V.; Bussi, C.; Plenet, D.; Lescourret, F. Effects of limiting irrigation and of manual pruning on brown rot incidence in peach. Crop Prot. 2008, 27, 678-688. [CrossRef]

70. Bussi, C.; Plenet, D.; Merlin, F.; Guillermin, A.; Mercier, V. Limiting brown rot incidence in peach with tree training and pruning. Fruits 2015, 70, 303-309. [CrossRef]

71. Gilbert, C.; Chadœuf, J.; Vercambre, G.; Génard, M.; Lescourret, F. Cuticular cracking on nectarine fruit surface: Spatial distribution and development in relation to irrigation and thinning. J. Am. Soc. Hortic. Sci. 2007, 132, 583-591. [CrossRef]

72. Bellingeri, M.; Quilot-Turion, B.; Lino, L.O.; Bevacqua, D. The crop load affects brown rot progression in fruit orchards: High fruit densities facilitate fruit exposure to spores but reduce the infection rate by decreasing fruit growth and cuticle cracking. Front. Ecol. Evol. 2018, 5, 1-7. [CrossRef]

73. Elmer, P.A.G.; Spiers, T.M.; Wood, P.N. Effects of pre-harvest foliar calcium sprays on fruit calcium levels and brown rot of peaches. Crop Prot. 2007, 26, 11-18. [CrossRef]

74. Thomidis, T.; Tsipouridis, C.; Michailides, Z.; Exadaktylou, E. Effect of zinc on the leaf mineral content, yield, fruit weight and susceptibility of peaches to Monilinia laxa. Aust. J. Exp. Agric. 2006, 46, 1203-1205. [CrossRef]

75. Thomidis, T.; Karagiannidis, N.; Stefanou, S.; Paresidou, M.; Prodromou, I. Influence of boron applications on preharvest and postharvest nectarine fruit rot caused by brown rot. Australas. Plant Pathol. 2017, 46, 177-181. [CrossRef]

76. De Melo, G.W.B.; Sete, P.B.; Ambrosini, V.G.; Freitas, R.F.; Basso, A.; Brunetto, G. Nutritional status, yield and composition of peach fruit subjected to the application of organic compost. Acta Sci. Agron. 2016, 38, 103-109. [CrossRef]

77. Gibert, C.; Chadœuf, J.; Nicot, P.; Vercambre, G.; Génard, M.; Lescourret, F. Modelling the effect of cuticular crack surface area and inoculum density on the probability of nectarine fruit infection by Monilinia laxa. Plant Pathol. 2009, 58, 1021-1031. [CrossRef]

78. Lee, M.-H.H.; Bostock, R.M. Fruit exocarp phenols in relation to quiescence and development of Monilinia fructicola infections in Prunus spp.: A role for cellular redox? Phytopathology 2007, 97, 269-277. [CrossRef] [PubMed]

79. Garcia-Benitez, C.; Melgarejo, P.; Sandin-España, P.; Sevilla-Morán, B.; De Cal, A. Degrading enzymes and phytotoxins in Monilinia spp. Eur. J. Plant Pathol. 2019, 154, 305-318. [CrossRef]

80. Abate, D.; Pastore, C.; Gerin, D.; De Miccolis Angelini, R.M.; Rotolo, C.; Pollastro, S.; Faretra, F. Characterization of Monilinia spp. Populations on Stone Fruit in South Italy. Plant Dis. 2018, 102, 1708-1717. [CrossRef] [PubMed]

81. Garcia-Benitez, C.; Melgarejo, P.; De Cal, A.; Fontaniella, B. Microscopic analyses of latent and visible Monilinia fructicola infections in nectarines. PLoS ONE 2016, 11, e0160675. [CrossRef]

82. Baró-Montel, N.; Vall-llaura, N.; Usall, J.; Teixidó, N.; Naranjo-Ortíz, M.A.; Gabaldón, T.; Torres, R. Pectin methyl esterases and rhamnogalacturonan hydrolases: Weapons for successful Monilinia laxa infection in stone fruit? Plant Pathol. 2019, 68, 1381-1393. [CrossRef]

83. Garcia-Benitez, C.; Melgarejo, P.; De Cal, A. Fruit maturity and post-harvest environmental conditions influence the prepenetration stages of Monilinia infections in peaches. Int. J. Food Microbiol. 2017, 241, 117-122. [CrossRef] [PubMed]

84. Yamamoto, T.; Kudo, M.; Watanabe, S. Fruit cracking and characteristics of fruit thickening in 'Satonishiki'cherry. J. Jpn. Soc. Hortic. Sci. 1990, 59, 325-332. [CrossRef]

85. Gibert, C.; Lescourret, F.F.; Génard, M.; Vercambre, G.; Perez Pastor, A.; Pérez Pastor, A. Modelling the effect of fruit growth on surface conductance to water vapour diffusion. Ann. Bot. 2005, 95, 673-683. [CrossRef] [PubMed]

86. Christensen, J.V. Cracking in cherries: VI. Cracking susceptibility in relation to the growth rhythm of the fruit. Acta Agric. Scand. 1973, 23, 52-54. [CrossRef]

87. Ohta, K.; Hosoki, T.; Matsumoto, K.; Ohya, M.; Ito, N.; Inaba, K. Relationships between fruit cracking and changes of fruit diameter associated with solute flow to fruit in cherry tomatoes. J. Jpn. Soc. Hortic. Sci. 1997, 65, 753-759. [CrossRef]

88. Papavasileiou, A.; Tanou, G.; Samaras, A.; Samiotaki, M.; Molassiotis, A.; Karaoglanidis, G. Proteomic analysis upon peach fruit infection with Monilinia fructicola and Monilinia laxa identify responses contributing to brown rot resistance. Sci. Rep. 2020, 10, 7807. [CrossRef] [PubMed]

89. Ziosi, V.; Noferini, M.; Fiori, G.; Tadiello, A.; Trainotti, L.; Casadoro, G.; Costa, G. A new index based on vis spectroscopy to characterize the progression of ripening in peach fruit. Postharvest Biol. Technol. 2008, 49, 319-329. [CrossRef]

90. Zhang, B.; Peng, B.; Zhang, C.; Song, Z.; Ma, R. Determination of fruit maturity and its prediction model based on the pericarp index of absorbance difference (IAD) for peaches. PLoS ONE 2017, 12, e0177511. [CrossRef] [PubMed]

91. Gradziel, T.M.; Bostock, R.M.; Adaskaveg, J.E. Resistance to brown rot disease in peach is determined by multiple structural and biochemical components. Acta Hortic. 2003, 622, 347-352. [CrossRef]

92. Feliziani, E.; Lichter, A.; Smilanick, J.L.; Ippolito, A. Disinfecting agents for controlling fruit and vegetable diseases after harvest. Postharvest Biol. Technol. 2016, 122, 53-69. [CrossRef]

93. Fourie, J.F.; Holz, G. Artificial inoculation of stone fruit with Botrytis cinerea, Monilinia laxa and Rhizopus stolonifer*. Phytophylactica $1985,181,179-181$. 
94. Janisiewicz, W.J.; Biggs, A.R.; Jurick, W.M.; Vico, I.; Conway, W.S. Biological characteristics of Monilinia fructicola isolates from stone fruits in eastern West Virginia. Can. J. Plant Pathol. 2013, 35, 315-327. [CrossRef]

95. Spadoni, A.; Cappellin, L.; Neri, F.; Algarra Alarcon, A.; Romano, A.; Guidarelli, M.; Gasperi, F.; Biasioli, F.; Mari, M. Effect of hot water treatment on peach volatile emission and Monilinia fructicola development. Plant Pathol. 2015, 64, 1120-1129. [CrossRef]

96. De Cal, A.; M.-SAGASTA, E.; Melgarejo, P. Biological control of peach twig blight (Monilinia laxa) with Penicillium frequentans. Plant Pathol. 1990, 39, 612-618. [CrossRef]

97. Tamm, L.; Fluckiger, W. Influence of temperature and moisture on growth, spore production, and conidial germination of Monilinia laxa. Phytopathology 1993, 83, 1321-1326. [CrossRef]

98. Phillips, D.J. Effect of Temperature on Monilinia fructicola Conidia Produced on Fresh Stone Fruits. Plant Dis. 1984, 68, 610. [CrossRef]

99. Obi, V.I.; Barriuso, J.J.; Gogorcena, Y. Peach Brown Rot: Still in Search of an Ideal Management Option. Agriculture 2018, 8, 125. [CrossRef]

100. Luo, Y.; Michailides, T.J.; Morgan, D.P.; Krueger, W.H.; Buchner, R.P. Inoculum dynamics, fruit infection, and development of brown rot in prune orchards in California. Phytopathology 2005, 95, 1132-1136. [CrossRef] [PubMed]

101. Mwamburi, L.A.; Laing, M.D.; Miller, R.M. Effect of surfactants and temperature on germination and vegetative growth of Beauveria bassiana. Brazilian J. Microbiol. 2015, 46, 67-74. [CrossRef]

102. Rodríguez-Pires, S.; Garcia-Companys, M.; Espeso, E.A.; Melgarejo, P.; de Cal, A. Influence of light on the Monilinia laxa-stone fruit interaction. Plant Pathol. 2021, 70, 326-335. [CrossRef]

103. Tian, S.P.; Bertolini, P. Effect of temperature during conidial formation of Monilinia laxa on conidial size, germination and infection of stored nectarines. J. Phytopathol. 1999, 147, 635-641. [CrossRef]

104. Peschel, S.; Knoche, M. Characterization of microcracks in the cuticle of developing sweet cherry fruit. J. Am. Soc. Hortic. Sci. 2005, 130, 487-495. [CrossRef]

105. Schumann, C.; Winkler, A.; Brüggenwirth, M.; Köpcke, K.; Knoche, M. Crack initiation and propagation in sweet cherry skin: A simple chain reaction causes the crack to 'run'. PLOS ONE 2019, 14, e0219794. [CrossRef]

106. Mishra, S.; Kumar, P.; Malik, A. Evaluation of Beauveria bassiana spore compatibility with surfactants. Int. J. Med. Heal. Sci. 2013, 7, 8-12.

107. Oliveira, D.G.P.; Pauli, G.; Mascarin, G.M.; Delalibera, I. A protocol for determination of conidial viability of the fungal entomopathogens Beauveria bassiana and Metarhizium anisopliae from commercial products. J. Microbiol. Methods 2015, 119, 44-52. [CrossRef]

108. Bradshaw, A.D. Evolutionary Significance of Phenotypic Plasticity in Plants. Adv. Genet. 1965, 13, 115-155. [CrossRef]

109. Pascal, T.; Kervella, J.; Pfeiffer, F.G.; Sauge, M.H.; Esmenjaud, D. Evaluation of the interspecific progeny Prunus persica cv Summergrand $\times$ Prunus davidiana for disease resistance and some agronomic features. Acta Hortic. 1998, 465, 185-191. [CrossRef] 